\title{
Modeling trophic interactions in Lake Kivu: What roles do exotics play?
}

\author{
Maria Concepcion S. Villanueva ${ }^{a, b}{ }^{*}$, Mwapu Isumbisho ${ }^{c}$, Boniface Kaningini ${ }^{c}$, Jacques \\ Moreau $^{b}$ and Jean-Claude Micha ${ }^{d}$
}

\footnotetext{
a Laboratoire des Ressources Halieutiques, IFREMER, Avenue du Général de Gaulle, BP 32, 14520 Port-enBessin Huppain, France

${ }^{\mathrm{b}}$ Department of Tropical Fisheries, Laboratoire d'Agronomie, Environnement et Ecotoxicologie, INP/ENSAT, BP 32607, 31326 Castanet Tolosan, France

c UERHA, Département de Biologie, Institut Supérieur Pédagogique de Bukavu, BP 854, Bukavu, People's Republic of Congo

d URBO, FUNDP, Rue de Bruxelles 61, B-5000 Namur, Belgium
}

*: Corresponding author : Maria Concepcion S. Villanueva, Tel.: +33 2315 15637; fax: +33 2315 15601, email address : Ching.Villanueva@ifremer.fr

\begin{abstract}
:
An Ecopath model of the southern part of Lake Kivu, a deep African equatorial lake was constructed to quantitatively describe the possible impact of fish introductions in this ecosystem. This study is considered as an initial step in summarizing ecological and biological information, under a coherent framework, on this ecosystem. Fourteen compartments were considered. As a phytoplankton-based food web, it is observed that key food sources are not fully utilized as transfer efficiencies per trophic levels (TL) varies between 4.5 and $9.4 \%$. Zooplankton plays a major role in transferring organic matter from TL1 to higher TLs due to the abundance of zooplanktivores. Shifts in food preferences and distribution of some of the fish functional groups were observed as a response to competition. The majority of fish biomass concentration is in TL3 (55\%). The fishery is concentrated at TL3 and can, therefore, be consider as "immature", sensu Odum. The direct and indirect effects of predation between system components (i.e. fish, invertebrates, phytoplankton and detritus) are quantitatively described and the possible influence and role in the ecosystem's functioning of introduced fish species are discussed.
\end{abstract}

Keywords: Food web structure; Transfer efficiency; Invasion; Exotic fishes; Lake Kivu

\section{Introduction}

Introduction of alien species in aquatic ecosystems is stimulated by increasing demand for food to sustain increasing human population and poverty, enhance fish stocks, generate economic benefits, as biomanipulation stratagem and sustain recreational fisheries (Welcomme, 1988 Welcomme, R.L., 1988. International Transfers of Inland Fish Species. FAO Fisheries Technical Papers 294, 318 pp.[Welcomme, 1988], [Pitcher and Hart, 1995], [Irz et al., 2004] and [Saltveit, 2006]). However, this strategy is often unacceptable as it leads to detrimental impacts on ecology of wild stocks that frails ecosystem structure ([Wilcove et al., 1998], [Lodge et al., 1998], [Allen and Humble, 2002], [Kolar and Lodge, 2002], [Sax and Gaines, 
2003; Gurevitch and Padilla, 2004; Didham et al., 2005; Arim et al., 2006), fisheries economy

(Mack et al., 2000; Pimentel et al., 2001) and recreation (Winfield and Durie, 2004).

Widespread introductions of non indigenous species have been categorized as a major cause of natural species extinction compared to habitat fragmentation (MacDonald et al., 1989;

Lodge et al., 1998; Davis and Thompson, 2000; Allen and Humble, 2002; Sax and Gaines, 2003;

Gurevitch and Padilla, 2004; Didham et al., 2005; Arim et al., 2006) in both terrestrial

(Rejmánek and Richardson, 1996; McCann, 2000; Smith et al., 2000; Allen and Humble, 2002;

Guo et al., 2006; Lovett et al., 2006) and aquatic systems (Mills et al., 1993; Pitcher and Hart, 1995; Puth and Post, 2005; Latini and Petrere Jr., 2004; Dudgeon et al., 2006). Although in the latter, biological invasions have been recognized as a persisting problem compared to pathologic crisis in terrestrial ecosystems (Dudegeon et al., 2006).

Questions on success of exotics and the damaging impacts to native stocks at the ecosystem level have fascinated many ecologists, such as Crawley (1987), Naeem et al. (2000) and Kennedy et al. (2002). Ecological systems are extremely complex networks, consisting of many biological species that interact in many different ways, such as mutualism, competition, parasitism and feeding relationships. The latter can cause invasions, extirpations, and population fluctuations of a species to dramatically affect other species within a variety of natural habitats

44 (Pimentel et al., 2001; Winfield and Durie, 2004). According to Hobbs (1989), successful invasion in natural communities depend on species dispersal, establishment and survival with the number of species per area established by immigration-extinction equilibrium. Success of exotics also depends on tolerance and broad ecological demands, ability to adapt to habitat and environmental conditions and r-selected life histories (Craig, 1992; Murichi et al., 1995). 
Cases where introduction of exotics have been reported beneficial are rare in both

51

52

terrestrial (Schutzenhofer and Valone, 2006) and aquatic ecosystems (Gottlieb and

Schweighofer, 1996). Elevated biodiversity has been observed to increase resistance from invasions in terrestrial and aquatic systems by creating insurance through functional redundancy (Simberloff and Von Holle, 1999; Sax and Brown, 2000; Naeem et al., 2000; Kennedy et al., 2002; Raffaelli et al., 2002; Stachowicz et al., 2002).

The importance of considering a trophic network approach is that it can elucidate feeding relationships which occur between species in an ecological community and determine functional roles of species groups in the ecosystem (Yodzis and Winemiller, 1999). Indeed, numerous evidences suggest that food web structures are susceptible to a wide array of human activities, including species introductions or invasions (Vander Zanden et al., 1999), habitat alteration (Wootton et al., 1996), and global environmental warming (Petchey et al., 1999). Lakes where exotic species were introduced (Moreau, 1995; Moreau et al., 1993; 2001; Villaneuva and Moreau, 2001). A similar approach has been carried out in other African lakes, i.e. Lake Victoria (Moreau, 1995; Villanueva and Moreau 2001), Lake Naivasha (Mavuti et al., 1996; Moreau et al., 2001) or Lake Kariba (Moreau, 1997), to determine the state of biologic community alterations following fish introductions. As effects of fish introductions and its exploitation on the community and ecosystem level are still unknown in Lake Kivu. The aim of the present contribution is to study the food web structure, species interactions, role of exotics in the ecosystem and compare these to observations in other tropical lakes where fish introductions 
occurred. Understanding trophic links is crucial in predicting future impact of species invasion in natural food web structure and functioning.

\section{Material and Methods}

\section{Study site}

Lake Kivu (Fig.1) has a surface area of $2370 \mathrm{~km}^{2}$ of which $1370 \mathrm{~km}^{2}$ is a part of the Congolese territory. An international aquatic system situated along the Congo-Rwanda border at an altitude of $1463 \mathrm{~m}$. It is located between $1^{\circ} 30^{\prime}$ and $2^{\circ} 30^{\prime}$ latitude south and between $28^{\circ} 50^{\prime}$ and $29^{\circ} 23^{\prime}$ longitude east. It is a deep (maximum depth $490 \mathrm{~m}$ ) equatorial lake with an average water depth of about $240 \mathrm{~m}$. The littoral area stretches not further than $50 \mathrm{~m}$ away from the lake’s extensive (1200 km) shoreline (Van den Bossche and Bernascek, 1990; Verheyen et al., 2003). It is a meromictic lake with deep relict hypolimnion where beneath lies a vast methane gas reserves (Coulter et al., 1984; Snoeks, 1994). Permanent water stratification is observed: anoxic below $60 \mathrm{~m}$ while the deeper part of the lake is methane saturated (Coulter et al., 1984; Van den Bossche and Bernascek, 1990; Isumbisho et al., 2006; Sarmento et al., 2006). Annual precipitation in the region is about $1300 \mathrm{~mm}$, relatively higher along the occidental than the oriental side of the lake, which experiences virtually no variations in water level. The average surface water temperature is about $24^{\circ} \mathrm{C}$ (Snoeks, 1994).

Several lakes of the East African Rift Valley are characterized by a deep pelagic zone which is colonized by abundant native small pelagic fish (Coulter et al., 1984; Lowe-McConnell, 1993). A well documented exception among these lakes is Lake Kivu. Compared to other lakes of the Rift Valley the fish diversity is relatively poor with only 26 endemic species belonging to 
the Cichlidae, Clariidae, Cyprinidae and Clupeidae families (Hanek et al., 1991; Snoeks, 1994). The Cichlids are the most represented with 17 endemic haplochromines (De Vos et al., 2001).

Exotic fishes were introduced to increase biodiversity and productivity of the lake (Welcomme, 1988). Fish stocking in Lake Kivu dates back in the 1950s where two cichlids, Oreochromis macrochir (Boulenger) and Tilapia rendalli (Boulenger), were introduced due to the renowned ecological plasticity of these species (Chapman et al., 2003; De Vos et al., 2001). Two endemic sardines of Lake Tanganyika, Limnothrisssa miodon (Boulenger) and Stolothrissa tanganyicae (Regan), were then simultaneously introduced in 1959 (Van den Bossche and Bernascek, 1990; Spliethoff et al., 1983) to occupy the pelagic zone (90\%). S. tanganyicae, however, was not able to adapt to the local conditions in the lake (Hauser et al., 1995).

The Lake Kivu fishery is predominantly artisanal (Van den Bossche and Bernacsek, 1990; Hanek et al., 1991; de Iongh et al., 1995) which is similar to other East African Lakes (Pitcher and Hart, 1995; Preikshot et al., 1998). In terms of the fishing activity, fishery in the site considered is the most important in the Congolese sector (Hanek et al., 1991). Annual production is generally observed higher in the Rwandese sector where fishing activities are more active and developed. At the zone considered in this study annual production in 1990 represented 20\% of overall production (Hanek et al., 1991; Marshall and Mubamba, 1993). Fishermen operate with various fishing gears depending on season, investment level, fishing areas and species targeted. A specific fishery, trimaran, uses light attraction and liftnet and selectively targets L. miodon and planktivore haplochromines (Van den Bossche and Bernacsek, 1990; Hanek et al., 1991; de Iongh et al., 1995; Kaningini et al., 1999). Beach seines capture mainly the benthopelagic haplochromines, but have been observed to accidentally catch other species such as L. miodon. 
121 Gillnets capture mainly tilapias although smaller mesh-sized (10 mm) nets are employed to trap

122 L. miodon and some haplochromines. Longlines target mainly Clarias species (Hanek et al., 123 1991).

The lake is an international area shared by Rwanda (East) and RD Congo (ex-Zaire,

West). For this study, we considered the Bukavu basin of the Congolese sector (Fig. 1) which is approximately $140 \mathrm{~km}^{2}$, as this zone is better documented in terms of biological community ecology and fisheries compared to the Rwandese sector. This zone also represents an important socio-economic aspect (Hanek et al., 1991). It should be noted that parameters integrated in the model were mainly estimated using data collected in this area.

\section{Theoretical Approach}

We used the Ecopath model (Christensen and Pauly, 1993; Christensen et al., 2005) to construct a steady-state description of the Bukavu Bay. The model has already been used for quantifications of food webs in different ecosystems to study the impact of fisheries for management purposes (Pauly et al., 2003; Christensen and Walters, 2004b). It comprises a set of simultaneous linear equations, one for each group under consideration, where the production of the group is equal to the sum of all predation, non-predatory losses and export:

$$
B_{i}-\frac{P}{B_{i}}=\sum_{j=1}^{n} B_{j}-\frac{Q}{B_{j}} D C_{j i}+B_{i}-\frac{P}{B_{i}}\left(1-E E_{i}\right)+E X_{i}
$$

143 where $B i$ is the biomass of group $i$ (in $t \mathrm{~km}-2$ fresh weight); $P / B i$ is the annual production/biomass

144 ratio of $i$ equal to the total mortality coefficient (Z) in steady-state conditions (Allen, 1971); $E E_{i}$ 
145 is the ecotrophic efficiency representing the part of the total production consumed by predators

146 or captured in the fishery or exported; $B_{j}$ is the biomass of the predator group $j ; Q / B_{j}$ is the annual

147 food consumption per unit biomass of the predatory group $j ; D C_{j i}$, is the proportion of the group $i$

148 in the diet of its predator group $j ; E X_{i}$, is the export or catch in fishery of group $i$, that is assumed

149 to be exploited in the fishery (Christensen et al., 2005).

150

In addition to balancing the model, Ecopath can be used to compute parameters and

152 indices corresponding to the food web characteristics. Some parameters that can be estimated using the software are as follows:

154

155

156

157

a.) The group-specific omnivory index $O I$ is computed as the variance of the TLs of each predator's prey groups (Christensen and Pauly, 1993) while the system omnivory index (SOI) is computed as the average omnivory index of all consumers weighted by the logarithm of each consumer's food intake $Q$ (Christensen et al., 2005). It indicates the allocation of predator170 prey interactions linking each TL (Christensen and Walters, 2004a). Both OI and SOI indices vary from 0 to 1 , where a value close to 0 indicates high predatory specialization (feeding on one trophic level only) and 1 indicates a maximum feeding versatility on several trophic levels.

162

163

b.) The connectance index $(C I)$ is the ratio between the number of actual definite trophic associations among all the groups and the theoretical possible number of connections, $(N-1)^{2}$ for $N$ groups, including consumption of detritus (Christensen and Walters, 2004a; Christensen et al., 2005). This index is correlated with the maturity e.g. the level of evolution of the ecosystem, as

167 defined by Odum (1969), of the ecosystem because the food chain structure changes from linear 168 to web-like as a system matures (Odum, 1971). 
170 c.) Niche overlap is measured by using a symmetrical index derived from the one proposed by

171 Pianka (1973) based on competition coefficients of the Lotka-Volterra equation (Volterra, 1931)

172 and derived from the Jaccard similarity index (Harris, 1968). It is used to describe mainly the 173 trophic aspect of niche partitioning. An index value close to 0 indicates that two groups have a

174 low resemblance in terms of food consumed and vise versa for a value close to 1 (Christensen et 175 al., 2005).

176

177 d.) Trophic aggregation per discrete $T L$, sensu Lindeman (1942), is based on an approach suggested by Ulanowicz (1995). This routine facilitates calculation of flows per TL based on diet compositions by reversing the routine for calculation of fractional trophic levels quoted above. More particularly, the transfer efficiencies between the successive discrete trophic levels are calculated as the ratio between the sum of the exports plus the flow that is transferred from one trophic level to the next, and the throughput at this trophic level (Christensen et al., 2005).

e.) The gross efficiency of the fishery $\left(G E_{F}\right)$ is computed as the ratio between the total catch and the total primary production in the system. The value will be higher for systems with a fishery harvesting fish belonging mainly to low TLs than for systems whose fisheries concentrate on high TLs. Therefore, this index may increase with fisheries 'development' as defined by Pauly et al. (1998). 
complemented by additional published works by Ulyel (1991), Snoeks (1994) and Kaningini et

194 al. (1999). For simplification purposes, species with similar ecological characteristics (i.e.

195 metabolism, diets and predators) were pooled together following the indications of Yodzis and

196 Winemiller (1999). In such a case, the biological characteristics of the most abundant species

197 were considered. A total of 14 groups were considered in this study and the ecological grouping

198 of biological assemblages is the following one.

199

Detritus: A standing stock of $165 t . \mathrm{km}^{-2}$ (fresh weight, fw) was calculated using the empirical equation of Pauly et al. (1993) based on an annual primary production estimated in the system (see below) and a euphotic zone of $32 \mathrm{~m}$. It is an input required to run the model (Christensen and Pauly, 1993).

Phytoplankton and primary production: The dominant groups are diatoms (Nitzschia spp and Fragilaria spp) and cryptophytes (Chroomonas spp and Rhodomonas spp). Chlorophyll-a concentration showed clear seasonal variations and increases during the dry season, after deep mixing in the basin of Bukavu (Ishumbisho et al., 2006; Sarmento et al., 2006). The average Chlorophyll- $a$ content is $1.53 \mathrm{mg} \mathrm{m}^{-3}$ for the area considered. It can be extrapolated over $60 \mathrm{~m}$ as suggested by Isumbisho et al. (2006) and the resulting fresh biomass $\left(32.1 \mathrm{t} \mathrm{km}^{-2} \mathrm{fw}\right)$ was used as an input in the model. The annual primary production was measured at $273 \mathrm{~g} \mathrm{C.m}{ }^{-2}$ by Sarmento et al. (2006) and concords with annual range values (240 - 379 gC.m²) indicated earlier by

213 Jannasch (1975), Van den Bossche and Bernacsek (1990) and Descy and Fourniret (1991). A

214 similar value was estimated using the Photosynthesis simulator of Capblanc and Dauta (1999).

215 Assuming $1 \mathrm{~g} \mathrm{C}$ is equal to $10 \mathrm{~g}$ fw (Sarvala et al., 1999). A P/B ratio of $85 \mathrm{yr}^{-1}$ was used as an 216 input in the model. 

copepods (Thermocyclops) and, to a lesser extent, cladocerans (Diaphanosoma) though seasonal density variations can be observed (Isumbisho et al., 2006). The average $B$ is 5.64 t.km² estimated from Isumbisho et al. (2006) and an annual $P / B$ value of $30 \mathrm{yr}^{-1}$ was used (Sarvala et al., 1999; Irvine and Waya, 1999). Q/B value of $180 \mathrm{yr}^{-1}$ was adopted from Sarvala et al. (1999).

Benthic fauna: Only limited information was available for this group. This includes benthic deposit feeders such as the nematodes, ostracods, insects, bivalve mollusks, gastropods and other benthic organisms which develop only along the littoral zone due to the relative steepness of the lake. A P/B value of $4.5 \mathrm{yr}^{-1}$ (Payne, 1986; Mavuti et al., 1996) was adopted and $Q / B$ of $45.0 \mathrm{yr}^{-1}$ was assumed from a gross efficiency (GE or $\left.P / Q\right)$ value of 0.1 (Christensen and Pauly, 1993). An input value of 0.900 for $E E$ was used to estimate the biomass based on intense predation noted from higher $T L$ consumers.

Fish groups: When possible the $B / P$ ratio was estimated from recently collected length frequency distributions by using the FiSAT software (Gayanilo et al., 2002). In a first step, this software was used to estimate the growth parameters of the von Bertalanffy growth function i.e., the asymptotic length $\left(L_{\infty}\right)$ and the growth coefficient $(K)$ which are needed for $P / B$ computation by reference to the length converted catch curve method. Otherwise, the predictive models of de Merona (1983) or Fröese and Binohlan (2000) were employed to estimate these demographical parameters. Natural mortality, $M$, was computed using the predictive formula of Pauly (1980). The demographical data of the fish populations considered here are summarized on Table 1. 
242 Maxims (Jarre et al., 1991), a software model based on the method of Pauly (1986) which allows

243 the computation of $Q / B$ from an estimate of the daily food consumption of individual fish of a

244 particular size. Otherwise, $Q / B$ was calculated using the multiple regression formula of

245 Palomares and Pauly (1998).

246

For most fish groups, local field data on diet composition were available. Additional information was taken from Snoeks (1994) and Ulyel et al. (1991).

The biomass $(B)$ of each fish group was estimated assuming equilibrium conditions, such that:

$$
B=Y / F
$$

where $Y$ is yield in $\mathrm{t}_{\mathrm{km}}^{-2} \cdot \mathrm{yr}^{-1}$ and $F$ is the coefficient of fishing mortality. $F$ is the difference between total and natural mortalities: $F=Z-M$, assuming that $Z$ is equal to $P / B$ as indicated by Allen (1971).

256

Due to habitat preferences of the species under investigation, the littoral area which is about $10 \%$ of the total surface of the lake (based on depth and bathymetry) was separated from the pelagic zone. The biomass of each compartment was calculated according to habitat area. For littoral groups, the biomass per $\mathrm{km}^{2}$ as computed as an average for the whole lake was, then, multiplied by 10 in order to express the concentration of this group in the littoral area.

Catch data and the proportion of each group in the total catch were obtained from various sources (i.e., Van den Bossche and Bernacsek, 1990) including unpublished data (J-C. Micha, 
FUNDP; B. Kaningini and M. Isumbisho, UERHA pers. comm.) recently collected as a part of an on-going Belgium Project for development of a gillnet fisheries in the lake.

The following groups were considered

269

$\left.1^{\circ}\right)$ Clarias spp: This group includes Clarias gariepinus (Burchell) and C. liocephalus

(Boulenger) which is quite rare in the lake and has been observed only in open waters. $C$. gariepinus has been considered as the key species for this group due to its predominance and well-studied ecological characteristics (B. Kaningini, UERAH, pers. comm.). Ulyel (1991) considered this species as a benthic polyphage, feeding on insects, crustaceans and fishes.

$\left.2^{\circ}\right)$ Raiamas moorei: This species, formerly known as Barilius moorei (Boulenger), is the only cyprinid inhabiting most areas of the lake. It feeds mainly on small bottom mollusks and insects, as well as on small cichlids and clupeids. $E E$ was set at 0.50 as this group is rarely targeted by fishermen and seems to be exposed to a limited predation by Clarias spp and Haplochromis vittatus (Boulenger).

$\left.3^{\circ}\right)$ Haplochromis spp: A list of 17 species was proposed and observed by Snoeks (1994). For the purpose of the present study, these species have been re-grouped based on their feeding ecology (Snoeks, 1994; Ulyel et al., 1991; Fourniret et al., 1992; Kaningini et al., 1999; Fröese and Pauly, 2006) into three groups:

- H. vittatus, a piscivore species which inhabits both the near shore and open waters.

- Benthos-feeding haplochromines are mostly H. gracilior (Boulenger), H. graueri 
(Regan). They inhabit the littoral areas and feed mainly on small mollusks, nematodes, insects and their larvae. The biological characteristics of $H$. graueri were considered since this is the most abundant among the benthophages.

- Plankton-feeding haplochromines are dominated by H. kamiranzovu (Snoeks) which was considered as the key species for this group. Diet compositions of haplochromine groups were adapted from Ulyel et al. (1991) and

Fourniret et al. (1992).

296

297

$\left.4^{\circ}\right)$ Limnothrissa miodon: This pelagic fish feeds mainly on zooplankton (Copepods) during its juvenile stage and may consume insects and small-sized fishes (de Iongh et al., 1983; Kaningini, 1995; Isumbisho et al., 2004). According to Pearce (1995), it is capable of adapting its diet preferences according to the local conditions (i.e., food availability), as this species is not specialized with regards to its preys. Demographic studies have been carried out by de Iongh et al. (1995) and Kaningini (1995). According to de Iongh et al. (1995), three length classes can be identified for this species based on condition factor changes. For this study, however, only two length classes were considered based on the length at first maturity (50\% of the gonads maturing) to separate the pelagic adults ( $>8.0 \mathrm{~cm}$ total length) from the sub littoral juveniles (< $8.0 \mathrm{~cm}$ total length). This repartition takes into account the difference of their spatial distribution

307 (Spliethoff et al., 1983; Lambœuf, 1991), spawning-related migrations (Marshall, 1991) and ontogenetic diet variations (de Iongh et al., 1983). Several studies on feeding patterns have also indicated occurrence of cannibalism (Spliethoff et al., 1983; Isumbisho et al., 2004).

It should be noted that the adults have a low $P / B$ ratio $\left(1.75 \mathrm{yr}^{-1}\right)$ compared to juveniles

312 (6.69 $\left.\mathrm{yr}^{-1}\right)$, a feature which was already noted when juveniles and adults are separated in an 
313 Ecopath model such as for Lates niloticus (Linnaeus) in Lake Victoria (Villanueva and Moreau,

314 2001). It is due to higher exploitation and predation on the latter, which are also integrated into

315 the adult pool. As juveniles sardines prey mainly on zooplankton and small benthos, their $Q / B$

316 values measured using MAXIMS are also higher (35.8 $\left.\mathrm{yr}^{-1}\right)$ than those of adults $\left(19.20 \mathrm{yr}^{-1}\right)$

317 which feed on zooplankton but also on small fish. In addition, small fish consume much more

318 food relatively to their size than larger ones (Pauly and Palomares, 1987).

319

320

$5^{\circ}$ ) Barbus spp inhabit near-shore area. This group includes Barbus kerstenii (Peters), $B$ pellegrini (Poll), B. pleurogramma (Boulenger) and B. altianalis (Boulenger). This group feeds basically on microphytes, insects and other benthic organisms, and on small littoral fishes (Ulyel, 1991; Kaningini et al., 1999; Fröese and Pauly, 2006). This group is one of the least consumed and exploited and least predated upon in the lake; $E E$ was, therefore, admitted to be 0.50 .

$\left.6^{\circ}\right)$ Oreochromis niloticus eduardianus (Boulenger) is an endemic, microphage fish inhabiting the littoral areas. It is the most abundant, native cichlid species in the lake due to its high fecundity (Trewavas, 1983).

$7^{\circ}$ ) Other Tilapiine fish include two introduced cichlid species, O. macrochir and T. rendalli), with the latter being more abundant possibly due to its efficient reproduction and feeding plasticity (Trewavas, 1983). In its original environment, T. rendalli is, however, regarded as a macrophyte-feeding species (Fröese and Pauly, 2006). Both inhabit the littoral areas of the lake and feed on macrophytoplankton and other organic material (Ulyel, 1991; Kaningini et al., 335 1999). 


\section{Results}

The basic input for each group and the parameters computed by the model are presented in Table 2 and 4, while the relative diet compositions are given in Table 3 whereas Figure 2 summarizes the main flows within this ecosystem. Total estimated fish biomass is low, 3.705 t.km², compared to other African inland waters (Christensen and Pauly, 1993). The resulting biomass for benthos looks low (3.676 t.km²) for the whole lake, though concentration along the littoral zones yields 36.76 t.km². This is in agreement with the importance of this group in the diets of several fish groups. A high abundance of zoobenthic organisms has already been noted in shallow areas of Lake George (Moreau et al., 1993) or Lake Ihéma (Mavuti et al., 1996).

Highest TLs were estimated for Clarias spp, $R$. moorei and $H$. vittatus (TL >3.3) due to their carnivorous feeding ecology (Table 3). Most groups belonging to TL3 and more are predatory carnivores.

351

\section{Ecotrophic efficiencies}

A low $E E$ value of 0.079 has been calculated for the detritus as most of it sinks to the bottom in the deepest parts of the lake. Phytoplankton has a higher EE of 0.633 , indicating that this group is the base food source in the lake even if it seems that it is not fully utilized by organisms of higher TLs, at least in this area of the lake. This may be attributed to the limited quantity of fish basically consuming this group. A high value of $E E$ is noted as well for zooplankton (0.764). Carnivorous zooplankton (Copepods) partly feed on the herbivorous zooplankton (mainly Cladocerans and Rotifers), as noted in the feeding matrix (Table 2) although they consume also phytoplankton. Ecotrophic efficiencies of fish groups are variable. 
361 For the two groups of Tilapiine fish, $E E$ is quite low $(E E=0.479$ and 0.233$)$, suggesting a very

362 limited exploitation and predation in the lake. The maximum $E E$ value (0.917) is recorded for $L$.

363 miodon juveniles, as we expected because these fish are exploited and predated.

364

365

The gross efficiencies

366

The $P / Q$ ratios (Table 4) are low for $R$. moorei and adult L. miodon. This might be due to

the low density of their prey, particularly the zooplankton, and the necessity for these fish to use

368 more energy for hunting their prey, which are available only at low densities. It should be noted that the density of zooplankton per volume basis is very low: 0.0914 g.m ${ }^{-3}$ fresh weight (Isumbisho et al., 2006). The low $P / Q$ ratios obtained for the 2 groups of Tilapiine fish (0.040 and 0.045 ) are in agreement with the low quality of their preferred preys which are principally phytoplankton and decaying organic material. A high $P / Q$ ratio is estimated for zoophagous haplochromines (0.202) due to their carnivorous feeding habits. The maximum value $(0.220)$ was obtained for the juveniles L. miodon and this is in relationship with their small size. This value is higher than for adults, which is in agreement with the basis of the method of computation of $Q / B$ implemented by Pauly and Palomares (1987). Ichthyophagous fishes (Clarias spp and $H$. vittatus) have surprisingly low $P / Q$ values. It might come from the scarcity of their possible prey in terms of biomass per volume unit.

\section{Omnivory indices and diet overlap}

The omnivory index $(O I)$ of each group is presented in table 4. In general, high $O I$ values are observed in high TLs, which indicate more complexity in this part of the food web. Highest OI are observed for three predators: Clarias spp, Barbus spp and H. vittatus (0.282, 0.349 and 0.339, respectively), and is related to their large feeding spectrum and distribution in the lake. 
These observations concord with the indication of Lindeman (1942) that prey tend to be more specialized than their predators.

Adults of L. miodon have a lower OI (0.153), than their juveniles $(0.218)$ due to the latter’s feeding flexibility (Isumbisho et al., 2004). Accordingly, our results indicate that, in habitats where it is already acclimated, L. miodon adjusts its trophic behavior to the availability of aquatic macro invertebrates. This has already been noted by Marshall (1995), Kaningini (1995) and recently by Isumbisho et al. (2004). Compared to H. vittatus, Haplochromines groups 4 and 5 have a lower $O I$ ( 0.155 and 0.179 , respectively), which suggests a higher specialization.

OI of O. niloticus is zero as this fish consumes only preys from the first trophic level, mainly phytoplankton (Table 3). Preference for phytoplankton of this species has been observed in other tropical lakes (Tadesse, 1999; Lu et al., 2006). Other Tilapiines, on the other hand, have a higher $O I$ due to their trophic plasticity, particularly for T. rendalli, that enables dietary shifts from plant or detrital material to animal material (Ulyel 1991; Kaningini et al., 1999).

400 with estimates of niche overlaps. L. miodon juveniles (group 7) have a low overlap as predator or 403 prey for most groups, except for the adults (group 6) which show high overlap in prey (Fig. 3).

404 Groups 9 (O. niloticus) and 10 (Other Tilapiines) show the highest overlap which suggests high 405 competition for similar resources. Groups 2 (R. moorei) and 7 have the lowest overlap which expresses divergent preferences in terms of resources consumed (Fig. 3). 

of 0.396 (Table 4). This $C I$ value is slightly higher than the theoretical value (0.317) computed using the regression model of Christensen and Pauly (1993). Both values can imply that most

411 functional groups exhibit a certain degree of diet specialization. This indicates as well the coexistence of weak and strong interactions observed among groups as expressed by the various $E E$ values (Table 2). According to Quince et al. (2002), this is common in food webs of especially competitive communities which might be the case here. Moreover, McCann (2000) indicated that recurrent food-web structures, with omnivory and apparent competition, can enhance ecosystem stability if the distribution of consumer-resource interaction strengths is skewed towards weak interaction strengths and McCann referred to as the "weak-interaction effect" which contributes to community-level stability.

\section{Biomass flux and transfer efficiency}

Trophic aggregation revealed that transfer efficiency from TL1 (phytoplankton and detritus groups combined) to higher TLs is about 8.4\%. This indicates that this resource may not be fully exploited due to the presence of herbivores in the littoral area, which makes up only $10 \%$ of the lake, leading to increased unconsumed nutrient accumulation (Table 5). The average transfer efficiency is at any $T L$ is less than $10 \%$ (Table 5). This is higher than that observed in other ecosystems such as Lake Navaisha (Moreau et al., 2001). Most of the fish biomass and ecological production take place at TL3 or more, as summarized in table 5. comes from primary producers while only 39\% originates from detritus (Table 5), a feature of relevance in a deep-water body (Christensen and Pauly, 1993). Most primary production is 
consumed by zooplankton and juveniles L. miodon. Detritus is consumed only by benthic fauna

433 (group 11) and, to a certain degree, by some fish groups: Barbus spp., O. niloticus and other

434 Tilapiines (Table 3). The elevated proportion of primary production flowing back to detritus

435 (about $65 \%$ of the total) is the result of increasing algal biomass surplus unconsumed, especially

436 in the open waters of the lake.

437

A high ratio between production and respiration (3.92) is noted. Most likely, a limited

quantity of organic matter is imported by inflowing rivers. An important part of the production of several groups is not utilized ( $E E$ is low) and is therefore lost as incorporated into the sediments on the bottom of the lake which has a deep anoxic hypolimnion. This might explain this unusually high value of the production/respiration value.

Fish productivity is linked to primary production by many intermediate trophic links. The primary production required (PPR) in order to support the fishery is $15.2 \%$ of the total primary production (Table 6) which is low compared to an average value suggested by Pauly and Christensen (1995) for tropical lakes and rivers (23.6\%). When expressed relative to the total flow from $T L 1$, the PPR (primary production required) used in Ecopath corresponds to the ecological footprint $(E F)$. For the catch the expression is $E F=P P R / P P^{*} C$ where $P P$ is the total

450 flow from $T L 1$, and $C$ the catch, will give the size of the area in $\mathrm{km}^{2}$, assuming the unit is, needed to sustain a catch of 1 ton for the given resource. As a consequence, a low ecological footprint (Folke and Kautsky, 1996) of the fishery $\left(0.04 \mathrm{~km}^{2}\right)$ is observed, similar to those observed by Villanueva et al. (2006) in two West African lagoons. 

et al., 1993), Lake Ihéma (Mavuti et al., 1996) and Lake Victoria (Villanueva and Moreau, 2001) or other tropical inland water bodies (Christensen and Pauly, 1993). The mean TL of the fishery is 2.9 (Table 6) as it targets mostly L. miodon.

459

Model predictions of the effects of environment changes

461

462

463

464

465

The mixed trophic impact (MTI) routine of Ecopath (Ulanowicz and Puccia, 1990) shows the direct and indirect influences of abundance variations of any species group on all other groups considered (Fig. 4). An initial condition that should be considered for this routine is that diet composition of each functional group does not change, despite possible variations in abundance of their various preys. An increased abundance of fish groups of high TLs (about 3 or more) would have various levels of negative impacts on other groups. This is particularly the case for Clarias spp (group 1) and L. miodon. An increasing abundance of non fish groups would generate a positive impact on most groups including fish groups. The impact of zooplankton biomass variations would be less important compared to the phytoplankton group. The extent of bottom-up control is elevated, as an increase in abundance of phytoplankton would have a strong positive effect on all higher TLs (Fig. 4), especially on the herbivores (groups 5, 9, 10 and 12).

A top-down trophic cascade effect (Pace et al., 1999; Persson, 1999) on phytoplankton biomass is also observed in the MTI simulation (Fig. 4). The primary productivity is increased due to the increase in planktivorous fish (TL3) that regulates herbivores, which in turn prey on phytoplankton. Hence, this may lead to a build-up of nonutilized phytoplankton. This was also experimentally observed by Lynch and Shapiro (1981). 
Figure 5 shows the susceptibility of some fish to human exploitation than others. Fishing

481

482

483

484

485

486

487

488

489

490

491

492

493

494

495

496

497

498

499

500

501

502

gears employed capture a specific species in the lake (Hanek et al., 1991). An increase of 10\% in the fishing effort shows a substantial increase in catch of target species, i.e. Clarias spp., Haplochromines, adult and juvenile L. miodon. Positive impacts on groups at lower TLs is a consequence of lower predation pressure when stock of fish predators decline due to increased fishing. An increasing fishing effort with beach seine and longline would have a slight negative impact on zooplankton. Both gears do not target $L$. miodon juveniles which are the principal predator of this group.

\section{Discussion}

Successful colonization of L. miodon in Lake Kivu has been attributed to the absence of other pelagic planktivores (de Iongh et al., 1995; Marshall, 1995; Munyandorero and Mwape, 2003) and low diversity of native species (Johannesson and Lambœuf, 1989). These combined with the relative stability of environmental factors suitable for its growth, provided opportunities for successful colonization of this sardine (Marshall, 1991; 1995) and other Cichlids.

Acclimatization of stocked species has been also observed in other African lakes such as Lakes Kyoga (Ogutu-Ohwayo, 1990), Kariba (Karenge and Kolding, 1995), Navaisha (Muchiri et al., 1995; Moreau et al., 2001), Nabugabo (Chapman et al. 1996) and Tana (de Graaf et al., 2000) as well as in other ecosystems in the world (Vitousek et al., 1997; Wilcove et al., 1998; Latini and Petrere Jr., 2004). Environmental condition modifications have already been cited as a major factor in enhancing long-term success and dominance of exotics species in several ecosystems (Muchiri et al., 1995; Smith et al., 2000; Dudgeon et al., 2006). 
The ability of $L$. miodon to coexist with other zooplanktivores may be essentially due to

505

506

507

508

509

510

511

512

513

514

515

516

517

518

519

520

521

522

523

524

525

526

spatial heterogeneity, thus, an absence of co-adapted competitors. Competition between similar functional groups may also alleviate indirect effects of predators on ecosystem processes and exhibits functional redundancy in ecosystems (Lawton and Brown, 1993; Loreau et al., 2001; Raffaelli et al., 2002; Stachowicz et al., 2002). Similar observations in other ecosystems were made in Lake Kariba (Karenge and Kolding, 1995), Parakrama Samudra reservoir (Moreau et al., 2001) and in the Great Lakes (Mills et al., 1993). Coexistence seems possible based on a competitive exclusion principle (Richards et al., 2000) by limiting competition through space budgeting (Isumbisho et al., 2003) between or within-guild species. Some haplochromines inhabit mostly the inshore zone while L. miodon occupies essentially the open waters. The significance of spatial heterogeneity in favoring increase of species abundance has also been observed by Le Pape et al. (2003) in the Bay of Biscay. Similar to L. miodon, naturalized tilapias still remain at limited levels without major impacts on the indigenous Nile Tilapia. Coexistence of both endemic and alien tilapias may be due to niche partitioning aside from the broad tolerance of tilapias against environmental changes (Murichi et al., 1995; Iwama et al., 1997; Khallaf et al., 2003). In Lake Kivu, these tilapias inhabit essentially the shallow waters (>10 m deep). The endemic O. niloticus eduardianus, however, is abundant in rocky bottoms while introduced Tilapiine fishes ( $O$. macrochir and, especially, T. rendalli) colonize better the muddy littoral zones (Trewavas, 1983). Spatial segregation limits competition for food and nursery sites similarly observed in Lakes Victoria and Kyoga (Twongo, 1995). O. niloticus and O. macrochir are both microphages which may explain the elevated prey-predator overlap (Fig. 3). Resistance of O. niloticus 
527 eduardianus may be mediated by its opportunistic behavior despite dietary overlap with $O$.

528 macrochir. Broadening of diet spectrum can increase a species tolerance to stress (Murichi et al., 529 1995; Sax and Brown, 2000; Wanink and Witte, 2000; Villanueva et al., 2006). Dietary shifts of

530 O. niloticus are similarly observed in Lake Victoria (Njiru et al., 2004).

531

532

This, however, may not apply to other species of lower environmental tolerance in the

lake. Low omnivory indices were observed for some groups, indicating a less diversified diet.

This is not the case for the sub-littoral inhabiting cichlids which contribute to the efficient

utilization of some resources, i.e. here the primary producers. Despite the low contribution of the detritus group, it is still utilized as a buffering agent in case of resource limitation. Similar observations were indicated by in Lake Navaisha (Munichi et al., 1995; Mavuti et al., 1996) and in some West African lagoons (Villanueva et al., 2006).

Both the predation-based regulation of the lower TLs and the resource-based regulation of the upper TLs are present in the ecosystem studied. The strength of both bottom-up and top-down controls determine system diversity though their relative importance and intensity which are based on the structure and functioning of groups among TLs (Herendeen, 2004). Differences in migration patterns and food availability may influence predation rates of predators, such as $C$. gariepinus, $H$. vittatus and L. miodon (Isumbisho et al., 2004). This is similar to observations of Bruton (1979) and Huddart (1994) in other African lakes. through the strong potential influence of any phytoplankton abundance variation on the whole food web. In ecological theory, bottom-up forces would dominate the ecosystem process (Platts 
551

552

553

554

555

556

557

558

559

560

561

562

563

564

565

566

567

568

569

570

571

572

573

574

and Ulanowicz, 1985; Dyer and Letourneau, 2003). According to Proulx et al. (1996),

production can also be modified through algal community structure modification as a function of variations in size distribution (Perin et al., 1996) or through predation-mediated modifications in plankton community structures (Hansson and Carpenter, 1993; Dyer and Letourneau, 2003).

Isumbisho et al. (2004) observed variations on zooplankton community abundance and distribution which is mainly due to predation by L. miodon juveniles and partly, in relation, to fishery practices. Predation-related variations within functional groups may lead to compensatory population increases by less vulnerable species in response to predation on vulnerable species (Steiner, 2001). Predation and competition affect aquatic communities indirectly by causing behavioral changes in prey species (Nyström et al., 2001; Steiner, 2001). Predation is an important part of ecosystem functioning though an increase in aggressive invaders or top predators can equally multiply effects of feeding interactions and contribute to reorganization of ecosystem structure indirectly (Fulton et al., 2003; Didham et al., 2005). Changes in zooplankton community structure have also been observed in Lake Donghu (China) by Yang et al. (2005) as a consequence of increased predation pressure of zooplanktivores. In Lake Victoria such phenomenon is attributed to eutrophication (Wanink et al., 2002).

The introduction of L. miodon and tilapias in the lake has surely improved energy transfer efficiencies in the lake, especially in the pelagic zone. Significant changes in functional roles at individual (i.e., changes in behavior and habitat use) and population (i.e. change in the abundance and distribution) levels were observed in the lake. Species change has also contributed to an entirely new configuration of the fisheries (Van den Bossche and Bernacsek, 1990; Preikshot et al., 1998). Compared to other ecopath-modeled deep lakes in Africa (see 
575 Villanueva and Moreau, 2001), however, there are many functional groups in Lake Kivu with 576 low EE values which imply that lower TLs are not saturated and predator abundance variations 577 can create vacant niches leaving unexploited resources in lower TLs. Functional consequences of 578 low biodiversity and species specific traits (i.e., size, trophic role, rarity, distribution and degree 579 of specialization) or combined effects of both may explain inefficiencies of energy transfers in 580 this lake. Lower energy transfer efficiencies in high TLs have been observed in other poorly diverse systems (Loreau et al., 2001; Raffaelli et al., 2002; Stachowicz et al., 2002).

582

Fish stocking is an important aspect of fishery management but comes with considerable risks. Invasive species can redefine an ecosystem by converting diverse communities into mono specific ones as introduced species often become invasive and may lead to native species extinctions (McKinney and Lockwood, 1999; Simberloff, 2000; Lodge, 2001; Rosenzweig, 2001; Davis and Thompson, 2000; de Graaf et al., 2000; Mack et al., 2000; Pimentel et al., 2001; Dudgeon et al. 2006). In African freshwater systems, an ominous example is the loss of biodiversity in Lake Victoria following the Nile perch introduction (Kudhongania and Chitamwebwa, 1995; Pitcher and Hart, 1995; Preikshot et al., 1998). Biodiversity in Lake Kivu, however, is low and fish were stocked to boost up the lake's biodiversity and productivity.

The role of biodiversity has been hypothesized as insurance to ecosystem functioning in case of modifications (Loreau et al., 2001). Biodiversity after introduction is affected in two manners either by global homogenization of regional biota or by affecting native species functions (Levine et al. 2003; Didham et al., 2005; Korniss and Caraco, 2005; Puth and Post, 2005; Olden and Rooney, 2006). Predators and resources manipulations can cause direct changes of diversity at one $T L$, which in turn, affect diversity of other TLs. Indirect biodiversity effects of 
varying resources and consumers, on the other hand, are supposed to be stronger in aquatic

600 ecosystems compared to terrestrial systems and detritus based food webs (Dyer and Letourneau, 601 2003). Intraspecific food resource limitation had been observed on adults of L. miodon which

602 had evolved from a mere pelagic planktivore to a piscivore, preying on its juveniles (Lowe-

603 McConnell, 1993). The sequestration of space and nutrients by adults may limit resources that 604 eventually provoked such cannibalistic behavior similar to observations of Mandima (1999) on

605 L. miodon in Lake Kariba and by Bundy and Pitcher (1995) on Nile Perch in Lake Victoria. 606 In Lake Kivu, however, fish introductions showed no detrimental changes at both the biodiversity and ecological levels of the fish community (Marshall, 1995; Ogutu-Ohwayo et al., 1997). It can be suggested that, under non-limiting food conditions, L. miodon which is occupying mainly the open waters of the lake do not have a particular deleterious effects on other

611 indigenous species, i.e. provoking mass extinction of the latter. It actually represents the lake's

612 most important stock in terms of biomass and production (Hanek et al., 1991). It has also

613 stimulated the commercial fishery with an estimated potential annual yield of $55 \mathrm{~kg} \cdot \mathrm{ha}^{-1}$ in the 614 early 90s (Johannesson and Lambœuf, 1989; van den Bossche and Bernacsek, 1990; Hanek et 615 al., 1991). At present, introduced fish species in this lake comprise 85\% of the catch (B.

616 Kaningini, UERHA, pers. data). A similar phenomenon observed in Lake Kariba (Coulter et al., 617 1984; Marshall and Mubamba, 1993). Despite the increasing intensity of the fishing activity on exotics, they seem resilient to human exploitation. Tilapias are known to be highly resilient to intensive fisheries due to their unspecialized ecological flexibility. Based on the classification of colonizers discussed by Davis and Thompson (2000), L.

622 miodon is a type 2 colonizer due to its eventual key role function in the ecosystem (Spliethoff et 
623 al., 1983; Isumbisho et al., 2006), especially in the fisheries (van den Bossche and Bernacsek,

624 1990; Marshall and Mabamba, 1993). In most cases, exotic fishes stocked have evolved

625 pervasive in other lakes not only in Africa (Mills et al., 1993; Ogutu-Ohwayo et al. 1997; de

626 Graaf et al., 2000) but worldwide (Villanueva and Moreau, 2001; Dudgeon et al., 2006). Once

627 the biodiversity is altered, the ecosystem is transformed into new configurations often

628 detrimental to human welfare (Ruesink et al., 1995; McCann et al., 2001; Pimentel et al., 2005;

629 Dudgeon et al., 2006; Lovett et al., 2006). In Lake Victoria, for example, the Nile Tilapia has

630 evolved as a "keystone species" though its introduction led to the alteration of ecosystem

631 function, biotic interactions and biotic homogenization (Moreau, 1995; Bundy and Pitcher, 1995,

632 Villanueva and Moreau 2001).

633

634 Conclusion

635

636

For this study, we have tried to quantify the impact of invasive species on ecosystem

637 process and functioning. Based on this study, energy fluxes from primary producers in this

638 ecosystem are largely phytoplankton-based because of the importance of zooplankton and abundance of zooplankton consumers. The fragility of the ecosystem to environmental changes

640 lies, therefore, in the production of the zooplankton group (TL 2), which evidently links the

641 transfer of primary production to higher TLs, and in the paucity of species diversity. The existing 642 competitions for food among some groups can be limited mostly by the specialization of some of

643 them to narrow spatial distributions.

644

Broad-scale or ecosystem-level approach is recognized as crucial in describing and understanding the trophic structure in Lake Kivu and the importance of the introduced species. It 
647 is a requirement to elucidate and, eventually, predict possible impact of exotic species on natural

648 food webs. Fish introductions in Lake Kivu is interesting in the sense that the introduction of

649 exotic species have increased energy flux transfers between TLs for what may have been initially

650 a 'dead zone' before the sardine colonization. Exotics play key role functions in the ecosystem

651 (Spliethoff et al., 1983; Isumbisho et al., 2006), especially in the fisheries (van den Bossche and

652 Bernacsek, 1990; Marshall and Mabamba, 1993). It is possibly one of the rare occasions where

653 introduction of exotics can be acknowledged as positive in terms stimulating commercial

654 fisheries (Johannensson and Lambœuf, 1989; van den Bossche and Bernacsek, 1990; Hanek et

655 al., 1991) and improving fish biodiversity with minor consequences on trophic structure and

656 functioning.

657

658 Acknowledgements

659

660

The authors wish to thank M. Masilya, M. Waasalo and H. Sarmento for useful

661

information and comments. M. Isumbisho acknowledges IFS (International Foundation for

662

Science) for financial support that allowed the completion of this work. The bulk of the field

663

work was supported by the "Agence Universitaire de la Francophonie” (AUF, Programme de

664 Coopération Scientifique Inter-Universitaire). Finally, we are indebted to the two anonymous

665 referees for valuable comments on the earlier version of the manuscript.

666

667 References

668

669 Allen, K.R. 1971. Relation between production and biomass. Journal of the Fisheries

670 Research Board of Canada, 28: 1573-1581. 
672 Allen, E.A. and Humble, L.M. 2002. Nonindigenous species introductions: A threat to Canada's 673 forests and forest economy. Canadian Journal of Plant Pathology, 24:103-10.

674

675 Arim, M., Abades, S.R., Neill, P.E., Lima, M. and Marquet, P.A. 2006. Spread dynamics of 676 invasive species. Proceedings of the National Academy of Sciences, 103(2): 374-378.

677

678 Bruton, M.N. 1979. The role of diel inshore movements by Clarias gariepinus (Pisces:

679 Clariidae) for the capture of fish prey. Transactions of the Zoological Society of London, 35: $680 \quad 115-138$.

681

682 Bundy, A. and Pitcher, T.J. 1995. An analysis of species changes in Lake Victoria: did the Nile 683 perch act alone?, pp. 111-135. In: T. Pitcher and P.J.B.Hart (Eds.), The impact of Species 684 Changes in African Lakes. Fish and Fisheries Series, 18, Chapman and Hall, London. 685

686 CapBlanc, J. and Dauta, A. 1999. Photosynthesis simulator ver 2.1. Université Paul Sabatier and 687 C.N.R.S., Toulouse.

688

689 Chapman, L.J., Chapman, C.A., Ogutu-Ohwayo, R., Chandler, M., Kaufman, L. and Keiter, A.E. 690 1996. Refugia for endangered species from an introduced predator in Lake Nabugabo, 691 Uganda. Conservation Biology, 10: 554-561.

692

693 Christensen, V. and Pauly, D. (Eds.) 1993. Trophic Models of Aquatic Ecosystems. ICLARM 694 Conference Proceedings, 26: 390 pp. 
695

696 Christensen, V. 1995. Ecosystem maturity - towards quantification. Ecological Modelling, 77:

$697 \quad 3-32$.

698

699 Christensen, V. and Walters, C. 2004a. Ecopath with Ecosim: methods, capabilities and

700 limitations. Ecological Modelling, 172: 109-139.

701

702 Christensen, V. and Walters, C. 2004b. Trade-offs in ecosystem-scale optimization of fisheries

703 management policies. Bulletin of Marine Science, 74 (3): 549-562.

704

705

Christensen, V., Walters, C. and Pauly, D. 2005. Ecopath with Ecosim: a User’s Guide. Fisheries

706 Centre Research Reports, 12 (4): 154 pp.

707

708 Coulter, G.W., Allanson, B.R., Bruton, M.N., Greenwood, P.H., Hart, R.C., Jackson, P.B.N. and

709 Ribbink, A.J. 1984. Unique qualities and special problems of the African Great Lakes.

710 Environmental Biology of Fishes, 17(3): 161-183.

711

712 Craig, J.F. 1992. Human-induced changes in the composition of fish communities in the African

713 Great Lakes. Review in Fish Biology and Fisheries, 2: 93-124.

714

715 Crawley, M.J. 1987. What makes a community invasible?, pp. 429-453 In: A.J. Gray, M.J.

716 Crawley and P.J. Edwards (Eds.), Colonization, Succession and Stability. Blackwell Scientific

717 Publications, Oxford.

718 
Davis, M.A. and Thompson, K. 2000. Eight ways to be a colonizer, two ways to be an invader: a

720 proposed nomenclature scheme for invasion ecology. Bulletin of the Ecological Society of

721 America, 81: 226-230.

722

723

de Graaf, M., Dejen, E., Sibbing, F.A. and Osse, J.W.M. 2000b. Barbus tanapelagius, a new

724 species from Lake Tana (Ethiopia): its morphology and ecology. Environmental Biology of Fishes, 59: 1-9.

726

727

de Iongh, H.H., Splithoff, P.C. and Frank, V.G. 1983. Feeding habits of the clupeid Limnothrissa 728 miodon (Boulenger) in Lake Kivu. Hydrobiologia, 102: 113-122.

729

730

de Iongh, H.H., Spliethoff, P.C. and Roest, F. 1995. The impact of an introduction of sardine into Lake Kivu, pp. 278-297. In: T. Pitcher and P.J.B. Hart (Eds.), The impact of Species Changes in African Lakes. Fish and Fisheries Series 18, Chapman and Hall, London.

733

734

De Merona, B. 1983. Modèle de croissance des poissons d'eau douce d’Afrique. Revue d’Hydrobiologie Tropicale, $19: 1-12$.

736

Descy, J.-P. and Fourniret, Y. 1991. Quelques données récentes sur la production planctonique du lac Kivu (Rwanda), pp.147-149. In P. Vernet (Ed.), Hommage à F.A. FOREL, Proceedings of the $3^{\text {rd }}$ CILEF, Morges, Switzerland.

De Vos, L., Snoeks, J. and Thys van den Audenaerde, D.K. 2001. An annotated checklist of the fishes of Rwanda (East-central Africa) with historical data on introductions of commercially 
important species. Journal of East African Natural History, 90: 41-68.

Didham, R.K., Tylianakis, J.M., Hutchison, M.A., Ewers, R.M. and Gemmell, N.J. 2005. Are invasive species the drivers of ecological change? Trends in Ecology and Evolution, 20 (9): 470-474.

748

Dudgeon, D., Arthington, A.H., Gessner, M.O., Kawabata, Z.-I., Knowler, D.J., Lévêque, C.,

Naiman, R.J., Prieur-Richard, A.-H., Soto, D., Stiassny, M.L. and Sullivan, C.A. 2006.

Freshwater biodiversity: importance, threats, status and conservation challenges. Biology

Review, 81: 163-182.

753

754

Dyer, L.A. and Letourneau, D. 2003. Top-down and bottom-up diversity cascades in detrital vs.

755 living food webs. Ecology Letters, 6: 60-68.

756

757

Folke, C. and Kautsky, N. 1996. The ecological footprint concept for sustainable seafood production. Proceedings of the International Conference on “Ecosystem Management for

Sustainable Marine Fisheries” 19-23 February 1996. Monterey, California.

760

761

Fourniret, Y., Plisnier, P.D. and Micha, J.-C. 1992. Régime alimentaire de quatre espèces du 762 genre Haplochromis (Téléostéi, Cichlidae) du lac Ihéma (Rwanda) Annales de Limnologie, 28

763 (1): 57-69.

764

765 Fröese, R. and Binohlan, C. 2000. Empirical relationships to estimate asymptotic length, length at first maturity and yield at maximum yield per recruitment in fishes, with a simple method to 
evaluate length frequency data. Journal of Fish Biology, 56: 758-773.

768

769 Fröese, R. and Pauly, D. (Eds.) 2006. Fishbase. http://www.fishbase.org.

770

771 Fulton, E.A., Smith, A.D.M. and Johnson, C.R. 2003. Mortality and predation in ecosystem

772 models: is it important how these are expressed? Ecological Modelling, 169: 157-178.

773

774 Gayanilo, F.C. Jr., Sparre, P. and Pauly. D. (Eds.) 2002. The FAO-ICLARM Stock Assessment

775 Tools II (FiSAT II Ver. 1.0) FAO http://www.fao.org/fi/statist/fisoft/fisat/.

776

777 Gottlieb, S.J. and Schweighofer, M.E. 1996. Oysters and the Chesapeake Bay Ecosystem: A case 778 for exotic species introduction to improve environmental quality? Estuaries, 19 (3): 639-650.

780 Guo, Q., Qian, H., Ricklefs, R.E. and Xi, W. 2006. Distributions of exotic plants in eastern Asia 781 and North America. Ecology Letters, 9 (7): 827-834.

782

783 Gurevitch, J. and Padilla, D.K. 2004. Are invasive species a major cause of extinctions? Trends 784 in Ecology and Evolution, 19 (9): 470-474.

785

786 Hanek, G., Leendertse, K. and Farhani, B. 1991. Socio-Economic Investigations of Lake Kivu

787 Fisheries. UNDP/FAO Regional Project for Inland Fisheries Planning (IFIP), RAF/87/099-

788 TD/23/91 (En): 55 p.

789 
790 Hansson, L. and Carpenter, S.R. 1993. Relative importance of nutrient availability and food 791 chain size for community composition in phytoplankton. Ö̈kos, 67: 257-263.

792

793 Harris, Z. 1968. Mathematical Structures of Language, Wiley, New York. Var. pag.

794

795 Hauser, L., Carvalho, G.R. and Pitcher, T.J. 1995. Morphological and genetic differentiation of 796 the African clupeid Limnothrissa miodon 34 years after its introduction to Lake Kivu. Journal of 797 Fish Biology, 47: 127-144.

798

799 Herendeen, R.A. 2004. Bottom-up and top-down effects in food chains depend on functional 800 dependence: an explicit framework. Ecological Modelling, 171: 21-33.

801

802 Hobbs, R.J. 1989. The nature and effects of disturbance relative to invasions, pp. 389-405. In: J.

803 Drake, F. di Castri, R. Groves, F. Kruger, H. Mooney, M. Rejmanek and M. Williamsom (Eds.), 804 Ecological invasions: A global perspective. Wiley, Chichester.

805

806 Huddart, R. 1994. Aspects of biology of the Lake Tanganyika sardine, Limnothrissa miodon 807 (Boulenger) in Lake Kariba. African Journal of Tropical Hydrobiology and Fisheries, 5: 3180844.

809

810 Irvine, K. and Waya, R. 1999. Spatial and temporal patterns of zooplankton standing biomass 811 and production in Lake Malawi. Hydrobiologia, 407: 191-205.

812 
813 Irz, P., Argillier, C. and Proteau, J.-P. 2004. Contribution of native and non-native species to fish

814 communities in French reservoirs. Fisheries Management and Ecology, 11: 165-172.

815

816 Isumbisho, P., Kaningini, B., Descy, J-P. and Baras, E. 2004. Seasonal and diel variations in the

817 diet of the young stages of Limnothrissa miodon in Lake Kivu, Eastern Africa. Journal of

818 Tropical Ecology, 20: 1-11.

819

820 Isumbisho, P., Sarmento, H., Kaningini, B., Micha, J.-C. and Descy, J.P. 2006. Zooplankton of

821 Lake Kivu, East Africa: half a century after the Tanganyika sardine introduction. Journal of 822 Plankton Research, 28: 971-989.

823

824 Iwama, G.K., Takemura, A. and Takano, K. 1997. Oxygen consumption rates of tilapia in 825 freshwater, sea water and hypersaline sea water. Journal of Fish Biology, 51 (5): 886-894.

826

827

Jannasch, A.W. 1975. Methane oxidation in Lake Kivu (Central Africa). Limnology and

828

Oceanography, 20: 860-864.

829

830 Jarre, A., Palomares, M.L.D., Soriano, M., Sambilay, V. and Pauly, D. 1991. Some new

831 analytical and comparative methods for estimating the food consumption of fish. ICES Journal of

832 Marine Science, 193: 99-108.

833

834 Johannensson, K. and Lambœuf, M. 1989. Estimation acoustique de l'abondance de stock

835 d’Isambaza (Limnothrissa miodon) du lac Kivu, par une méthode basée sur le comptage des

836 échos de poissons, Gisenyi. RWA/87/012/TRAM/13, 64 pp.

837 
Kaningini, B. 1995. Étude de la croissance, de la reproduction et de l'exploitation de

839 Limnothrissa miodon au lac Kivu, bassin de Bukavu (Zaïre). Thèse de doctorat, FUNDP,

840 Presses Universitaires de Namur, Belgium, 211p.

841

842 Kaningini, B., Micha, J.-C., Vandenhaute, J., Platteau, J.-P., Watongoka, H., Merlard, C.,

843 Wilondja, M.K. and Isumbisho, P. 1999. Pêche du Sambaza au filet maillant dans le lac Kivu.

844 Rapport final du Projet ONG/219/92/Zaïre. Presses Universitaires de Namur, Belgium.

845

846 Karenge, L. and Kolding, J. 1995. Inshore fish population and species changes in Lake Kariba,

847 Zimbabwe, pp. 245-275. In T. Pitcher and P.J.B. Hart (Eds.), The impact of Species Changes

848 in African Lakes. Fish and Fisheries Series 18 Chapman and Hall, London.

849

850 Kennedy, T.A., Naeem, S., Howe, K.M., Knops, J.M.H., Tilman, D. and Reich P. 2002.

851 Biodiversity as a barrier to ecological invasion. Nature, 417: 636-638.

852

853 Khallaf, E.A., Galal, M. and Authman, M. 2003. The biology of Oreochromis niloticus in a

854 polluted canal. Ecotoxicology, 12: 405-416.

855

856 Kolar, C.S. and Lodge, D.M. 2002. Ecological predictions and risk assessment for alien fishes in

857 North America. Science, 298:1233-1236.

858

859 Korniss, G. and Caraco, T. 2005. Spatial dynamics of invasion: The geometry of introduced 860 species. Journal of Theoretical Biology, 233: 137-150.

861 
862 Kudhongania, A.W. and Chitamwebwa, D.B.R. 1995. Impact of environmental changes, species 863 introductions and ecological interactions on the fish stocks of Lake Victoria, pp. 19-32. In: T.

864 Pitcher and P.J.B. Hart (Eds.), The impact of Species Changes in African Lakes. Fish and 865 Fisheries Series 18, Chapman and Hall, London.

866

867 Lambœuf, M. 1991. Abondance et répartition du Limnothrissa miodon du lac Kivu, résultat des 868 prospections acoustiques d'avril 1989 à juin 1991. DOC/TR No. RWA/87/012/DOC/TR/46 869 (Fr) FAO, 41 p.

870

871 Latini, A.O. and Petrere Jr., M. 2004. Reduction of a native fish fauna by alien species: an 872 example from Brazilian freshwater tropical lakes. Fisheries Management and Ecology, 11: 7187379.

874

875 Lawton, J.H. and Brown, V.K. 1993. Redundancy in ecosystems, pp. 255-270. In: E.D. Schulze 876 and H.A. Mooney (Eds.), Biodiversity and ecosystem functions. Springer-Verlag.

877

878 Le Pape, O., Chauvet, F., Mahévas, S., Lazure, L., Guérault, G. and Désaunay, Y. 2003.

879 Quantitative description of habitat suitability for the juvenile common sole (Solea solea L.) and 880 contribution of different habitats to the adult population in the Bay of Biscay (France). Journal 881 of Sea Resources, 50: 139-149

882

883 Levine, J.M., Vilà, M., D’Antonio, C.M., Dukes, J.S., Grigulis, K. and Lavorel, S. 2003.

884 Mechanisms underlying the impact of exotic plant invasions. Philosophical Transactions of the 885 Royal Society of London, 270: 775-781. 
886

887 Lindman, R.L. 1942.The trophic dynamic aspect of ecology. Ecology, 23: 399-418.

888

889 Lodge, D.M. 2001. Lakes, pp. 277-313. In: F.S. Chapin III, O.E. Sala and E. Huber-Sannwald 890 (Eds.), Global biodiversity in a changing environment: scenarios for the 21st century. Springer891 Verlag, New York.

892

893 Lodge, D.M., Stein, R.A., Brown, K.M., Covich, A.P., Brönmark, C., Garvey, J.E. and

894 Klosiewski, S.P. 1998. Predicting impact of freshwater exotic species on native biodiversity:

895

challenges in spatial scaling. Australian Journal of Ecology, 23: 53-67

896

897

Loreau, M., Naeem, S., Inchausti, P., Bengtsson, J., Grime, J.P., Hector, A., Hooper, D.U., 898

Huston, M.A., Raffaelli, D., Schmidt, B., Tilman, D. and Wardle, D.A. 2001. Biodiversity and

899 Ecosystem Functioning: Current Knowledge and Future Challenges. Science, 294: 804-808.

900

901 Lovett, G.M., Canham, C.D., Arthur, M.A., Weathers, K.C. and Fitzhugh, R.D. 2006. Forest

902 ecosystem responses to exotic pests and pathogens in eastern North America. BioScience,

90356 (5): 395-405

904

905 Lowe-McConnell, R.H. 1993. Fish Faunas of the African Great Lakes: Origins, Diversity, and

906 Vulnerability. Conservation Biology, 7 (3): 634-643.

907

908 Lu, K., Jin, C., Dong, S., Gu, B. and Bowen, S.H. 2006. Feeding and control of blue-green algal

909 blooms by tilapia (Oreochromis niloticus). Hydrobiologia, 568: 111-120. 
911 Lynch, M. and Shapiro, J. 1981. Predation, enrichment and phytoplankton community structure.

912 Limnology and Oceanography, 26: 86-102.

913

914 MacDonald, I.A., Loope, L.L., Usher, M.B. and Hamann, O. 1989. Wildlife conservation and the

915 invasion of nature reserves by introduced species: a global perspective, pp. 215-255. In: J.A.

916 Drake, H.A. Mooney, F. di Castri, R.H. Groves, F.J. Kruger, M. Rejmdnek and M. Williamson

917 (Eds.), Biological invasions: A global perspective. John Wiley and Sons, Chichester.

918

919 Mack, R.N., Simberloff, D., Lonsdale, W.M., Evans, H., Clout, M. and Bazzaz, F.A. 2000.

920 Biotic invasions: Causes, epidemiology, global consequences, and control. Issues in Ecology, 5.

921

922 Mandima, J.J. 1999. Spatial and temporal variations in the food of the sardine Limnothrissa

923 miodon (Boulenger 1906) in Lake Kariba, Zimbabwe. Hydrobiologia, 407: 175-182.

924

925 Marshall, B.E. 1991. Seasonal and annual variations in the abundance of the clupeid

926 Limnothrissa miodon in Lake Kivu. Journal of Fish Biology, 39: 641-648.

927

928 Marshall, B.E. 1995. Why is Limnothrissa miodon such a successful introduced species and is

929 there anywhere else we should put it?, pp. 527-545. In: T.J. Pitcher \& P.J.B. Hart (Eds.), The

930 impact of species changes in African Lakes. Fish and Fisheries Series 18, Chapman and Hall,

931 London.

932 
Marshall, B.E. and Mubamba R. (Eds.) 1993. Biology, stock assessment and exploitation of

934 small pelagic fish species in the African Great Lakes Region. CIFA Occasional Paper 19, FAO,

935 Rome, 270 p.

936

937 Mavuti, K., Moreau, J., Munyandorero, J. and Pisnier, D. 1996. Analysis of trophic relationships

938 in two shallow equatorial lakes: Lake Naivasha (Kenya) and Lake Ihéma (Rwanda) using a

939 multispecifies trophic model. Hydrobiologia, 321: 89-100.

940

941 McCann, J. 2000. The diversity stability debate. Nature, 405: 228-233.

942

943 McKinney, M.L. and Lockwood, J.L., 1999. Biotic homogenization: A few winners replacing

944 many losers in the next mass extinction. Trends in Ecology and Evolution, 14: 450-453.

945

946 Mills, E.L., Leach, J.H., Carlton, J.T. and Secor, C.L. 1993. Exotic species in the Great Lakes:

947 A history of biotic crises and anthropogenic introductions. Journal of Great Lakes Research, 948 19(1): 1-54.

949

950 Moreau, J. 1995. Analysis of species changes in Lake Victoria using ECOPATH, a

951 multispecies trophic model, pp. 137-162. In T.J. Pitcher and P.J.B. Hart (Eds.), The impact of

952 species changes in African Lakes. Chapman Hall, London.

953

954 Moreau, J., Arrignon, J. and Jubb, R.A. 1988. Les introductions d'espèces étrangères dans

955 les eaux continentales africaines, pp. 395-426. In: C. Lévêque, M.N. Bruton and G.W. 
956 Ssentongo (Eds.), Biologie et écologie des poissons d’eau douce africains. Coll. Travaux Doc.

957 216, ORSTOM, Paris.

958

959 Moreau, J., Christensen, V. and Pauly, D. 1993. A trophic ecosystem model of Lake

960 George, Uganda, pp. 124-129. In V.Christensen and D. Pauly (Eds.), Trophic models of

961 aquatic ecosystems. ICLARM Conference Proceedings 26, ICLARM, Manila, Philippines.

962

963 Moreau, J., Mavuti, K. and Daufresne, T. 2001. A synoptic Ecopath model of biomass flows

964 during two different static ecological situations in Lake Nakuru (Kenya). Hydrobiologia, 458:

$965 \quad 63-74$.

966

967 Moreau, J., Villanueva, M.C., Amarasinghe, U.S. and Schiemer, F. 2001. Trophic relationships

968 and possible evolution under various fisheries management strategies in Sri Lankan reservoir, pp.

969 201-214. In. S.S. De Silva and P. Lynch (Eds.), Fisheries management and Aquaculture in

970 Southeast Asian Lakes and Reservoirs. ACIAR Publications 98, Canberra, Australia.

971

972 Munyandero, J. and Mwape, L. 2003. Some records of Lake Tanganyika Clupeid and Latid fish

973 species, pp. 132-155. In M.L.D. Palomares, B. Samb, T. Diouf, J.M. Vakily and D. Pauly

974 (Eds.), Fish biodiversity: local studies as basis for global interferences. ACP-EU Fisheries

975 Research Report 14, Brussels.

976

977 Murichi, S.M., Hart, P.J.B. and Harper, D. 1995. The persistence of the two introduced species in

978 Lake Navaisha, Kenya, in face of environmental variability and fishing pressure, pp. 229-319. In 
979 T. Pitcher ad P.J.B. Hart (Eds.), The impact of species changes in African Lakes. Fish and

980 Fisheries Series 18, Chapman and Hall, London.

981

982 Naeem, S., Knops, J.M.H., Tilman, D., Howe, K.M., Kennedy, T. and Gale, S. 2000. Plant

983 diversity increases resistance to invasion in the absence of covarying extrinsic factors. Oïkos, 91:

$984 \quad 97-108$.

985

986 Njiru, M., Okeyo-Owuor, J.B., Muchiri, M. and Cowx, I.G. 2004. Shifts in the food of the Nile

987 tilapia, Oreochromis niloticus (L.) in Lake Victoria, Kenya African Journal of Ecology, 42: 163988170.

989

990 Nyström, P., Svensson, O., Lardner, B., Broenmark, C. and Graneli, W. 2001. The influence of

991 multiple introduced predators on a littoral pond community. Ecology, 82 (4): 1023-1039.

992

993 Odum, E.P. 1969. The strategy of ecosystem development. Science, 104: 262-270.

994

995 Odum, E.P. 1971. Fundamentals of ecology. W.B. Saunders Co, Philadelphia, 574 pp.

996

997 Odum, W.E. and Heald, E.J. 1975. The detritus-based food web of an estuarine mangrove 998 community, pp. 265-286. In: L.E. Cronin (Ed.), Estuarine research Vol. 1. Academic Press, 999 New York.

1000

1001 Ogutu-Ohwayo, R. 1990. The decline of the native fishes of Lake Victoria and Kyoga (East 1002 Africa) and the impact of introduced species, especially Nile Perch, Lates niloticus, and Nile 
tilapia, Oreochromis niloticus. Environmental Biology of Fishes, 27: 81-96.

Ogutu-Ohwayo, R., Hecky, R.E., Cohen, A.S. and Kaufman, L. 1997. Human impacts on the

1006 African Great Lakes. Environmental Biology of Fishes, 50: 117-131.

1007

1008

Olden, J.D. and Rooney, T.P. 2006. On defining and quantifying biotic homogenization. Global

1009 Ecology and Biogeography, 15: 113-120.

1010

1011 Pace, M.L., Cole, J.J., Carpenter, S.R. and Kitchell, J.F. 1999. Trophic cascades revealed in

1012 diverse ecosystems. Trends in Ecology and Evolution, 14: 483-488.

1013

1014 Palomares, M.L. and Pauly, D. 1998. Predicting food consumption of fish populations as

1015 functions of mortality, food type, morphometrics, temperature and salinity. Marine and

1016 Freshwater Research, 49: 447-453.

1017

1018 Pauly, D. 1980. On the interrelationships between natural mortality, growth parameters and 1019 mean environmental temperature in 175 fish stocks. Journal of the International Council for 1020 the Exploitation of the Sea, 39(3): 175-192.

1021

1022

Pauly, D. 1986. A simple method for estimating the food consumption of fish population from

1023 growth data and food conversion experiments. Fisheries Bulletin, 84: 827-840.

1024

1025 Pauly, D. and Palomares, M.L. 1987. Shrimp consumption by fishes 992 in Kuwait waters, a 1026 methodology, preliminary results and their implication for management and research. Kuwait 
Bulletin of Marine Sciences, 8: 101-125.

1028

1029 Pauly, D. and Christensen, V. 1995. Primary production required to sustain global fisheries. $1030 \quad$ Nature, 374: 255-257.

1031

1032

Pauly, D., Christensen, V., Dalsgaard, J., Fröese, R. and Torres, F.C. Jr. 1998. Fishing down

1033 marine food webs. Science, 279: 860-863.

1034

1035

Pauly, D, Palomares, M.D. and Vakily, M. 2003. Trophic models of Northwest African marine

1036 ecosystems. In D. Pauly, M.D. Palomares and M. Vakily (Eds.), Marine Fisheries,

1037

Ecosystems and Societies in West Africa: Half a century of change, SIAP/EP/DT/03 24-28

1038 June 2002 Dakar, Senegal.

1039

1040 Pauly, D., Soriano-Bartz, M. and Palomares, M.L. 1993. Improved construction, parameterization and interpretation of steady-state ecosystem models, pp. 1-13. In V.

1042

Christensen and D. Pauly (Eds.), Trophic models of aquatic ecosystems. ICLARM Conference

Proceedings 26, ICLARM, Manila.

1044

1045

Payne, I.A. 1986. The ecology of tropical lakes and rivers. Wiley \& Sons, New York, 301 p.

1046

1047 Pearce, M.J. 1995. Effects of exploitation on the pelagic fish community in the south of Lake

1048 Tanganyika, pp. 425-441. In: T.J. Pitcher and P.J.B. Hart (Eds.), The impact of species

1049 changes in African Lakes. Fish and Fisheries Series 18 Chapman and Hall, London.

1050 
1051 Perin, S., Pick, F.R., Lean, D.R.S. and Mazumder, A. 1996. Effects of planktivorous fish and 1052 nutrient additions in primary production of shallow versus deep (stratified) lake enclosures.

1053 Canadian Journal of Fisheries and Aquatic Sciences, 53: 1125-1132.

1054

1055

Persson, L. 1999. Trophic cascades: abiding heterogeneity and the trophic level concept at the end of the road. Oïkos, 85: 385-397.

1057

1058

Petchey, O.L., McPhearson, P.T., Casey, T.M. and Morin P.J. 1999. Environmental warming alters food-web structure and ecosystem function. Nature, 402: 69-72.

1060

1061

Pianka, E.R. 1973. The structure of lizard communities. Annual Review of Ecology and

1062

Systematics, 4: 53-74.

1063

1064 Pimentel, D., McNair, S., Janecka, J., Wightman, J., Simmonds, C., O’Connell, C., Wong, E., 1065 Russel, L., Zern, J., Aquino, T. and Tsomondo, T. 2001. Economic and environmental threats of

1066 alien plant, animal, and microbe invasions. Agriculture, Ecosystems, and Environment, 84:120.

1068

1069

Pitcher, T.J. and Hart, P.J.B. (Eds.). 1995. The impact of species changes in African Lakes.

1070 Kluwer Academic, Dordrecht, The Netherlands, 640 p.

1071

1072 Platts, T. and Ulanowicz, R.E. (Eds.) 1985. Ecosystem theory for biological oceanography.

1073 Canadian Bulletin of Fisheries and AquaticSciences, 213: 260 p.

1074 
1075 Preikshot, D., Nsiku, E., Pitcher, T. and Pauly, D. 1998. An interdisciplinary evaluation of the 1076 status and health of African lake fisheries using a rapid appraisal. Journal of Fish Biology, 53 1077 (supplement A): 381-393.

1078

1079 Proulx, M., Pick, F.R., Mazumder, A., Hamilton, P.B. and Lean, D.R.S. 1996. Effects of 1080 nutrients and planktivorous fish on phytoplankton community structure versus deep (stratified) 1081 aquatic systems. Ecology, 77: 1556-1572.

1082

1083 Puth, L.M. and Post, D.M. 2005. Studying invasion: Have we missed the boat? Ecology Letters, 1084 8: $715-21$

1085

1086

Quince, C., Higgs, P.G. and McKane, A.J. 2002. Food web structure and the evolution of 1087 ecological communities, pp. 281-298. In M. Lässig and A. Valleriani (Eds.), Biology

1088 Evolution and Statistical Physics. Springer, Berlin.

1089

1090

Raffaelli, D., van der Putten, W.H., Persson, L., Wardle, D.A., Petchey, O.L., Koricheva, J., van 1091 der Heijden, M., Mikola, J. and Kennedy, T. 2002. Multi-trophic dynamics and ecosystem 1092 processes, pp. 147-154. In M. Loreau, S. Naeem and P. Inchausti (Eds.), Biodiversity and 1093 ecosystem functioning: Synthesis and perspectives. Oxford University Press, Oxford. 1094

1095 Rejmánek, M.D. and Richardson, M. 1996. What attributes make some plant species more 1096 invasive? Ecology, 77: 1655-1661.

1097

1098 Richards, S.A., Nisbet, R.M., Wilson, W.G. and Possingham, H.P. 2000. Grazers and diggers: 
exploitation competition and coexistence among foragers with different feeding strategies on a

1100 single resource. The American Naturalist, 155: 266-279.

1101

1102 Rosenzweig, M.L. 2001. The four questions: what does the introduction of exotic species do to

1103 diversity? Evolutionary Ecology Research 3: 361-367.

1104

1105 Ruesink, J.L., Parker, I.M., Groom, M.J. and Kareiva, P.M. 1995. Reducing the risks of

1106 non indigenous species introductions. BioScience, 45 (7): 465-467.

1107

1108 Saltveit, S.J. 2006. The effects of stocking Atlantic salmon, Salmo salar, in a Norwegian

1109 regulated river. Fisheries Management and Ecology, 13: 197-205.

1110

1111 Sarmento, H., Isumbisho, P. and Descy, J.P. 2006. Phytoplankton ecology of Lake Kivu (Eastern

1112 Africa). Journal of Plankton Research, 28: 815-8829.

1113

1114 Sarvala, J., Salonen, K., Järvinen, M., Aro, E., Huttula, T., Kotilainen, P., Kurki, H., Langenberg,

1115 V., Mannini, P., Peltonen, A., Plisnier, P.D., Vourinen, I., Möslä, H. and Lindqvist, O. 1999.

1116 Trophic structure of Lake Tanganyika: carbon flows in the pelagic food web. Hydrobiologia,

1117 407: 149-173.

1118

1119 Sax, D.F. and Brown, J.H. 2000. The paradox of invasion. Global Ecology and Biogeography,

1120 9: 363-371.

1121

1122 Sax, D.F. and Gaines, S.D. 2003. Species diversity: from global decreases to local increases. 
1123 Trends in Ecology and Evolution, 18 (11): 561-566.

1124

1125 Schutzenhofer, M.R. and Valone, T.J. 2006 Positive and negative effects of exotic Erodium

1126 cicutarium on an arid ecosystem. Biological Conservation, 132: 376-381.

1127

1128 Simberloff, D., Von Holle, B. 1999. Positive interactions of non-indigenous species: invasional 1129 meltdown? Biological Invasions, 1: 21-32.

1130

1131 Smith, S.D., Huwman, T.E., Zitzer, S.F., Charlet, T.N., Housman, D.C., Coleman, J.S.,

1132 Fenstermakerk, L.K., Seeman, J.R. and Nowak, R.S. 2000. Elevated CO2 increases productivity

1133 and invasive species success in an arid ecosystem. Nature, 408: 79-82.

1134

1135 Snoeks, J. 1994. The Haplochromines (Teleostei, Cichlidae) of Lake Kivu (East Africa): A

1136 taxonomic revision with notes on their ecology. Annales de Sciences Zoologiques, 270: 221-

11371102.

1138

1139 Snoeks, J., De Vos, L., Coenen, E. and Thys van den Audenaerde, D.T. 1990. Description de

1140 deux nouvelles espèces d'Haplochromis (Teleostei, Cichlidae) du Lac Kivu, Rwanda. Cybium, 1141 14(1): 63-76.

1142

1143 Spliethoff, P.C., De Iongh, H.H. and Frank, V.G. 1983. Success of the introduction of the

1144 freshwater clupeid Limnothrissa miodon (Boulenger) in Lake Kivu. Fisheries Management, 1145 14: 17-31.

1146 
1147 Stachowicz, J.J., Fried, H., Whitlatch, R.B. and Osman, R.W. 2002. Biodiversity, invasion

1148 resistance and marine ecosystem function: reconciling pattern and process. Ecology, 83: 2575-

11492590.

1150

1151 Steiner, C.F. 2001. The effects of prey heterogeneity and consumer identity on the limitation

1152 of trophic-level biomass. Ecology, 82: 2495-2506.

1153

1154 Tadesse, Z. 1999. The nutritional status and digestibility of Oreochromis niloticus L. diet in Lake

1155 Langeno Ethiopia. Hydrobiologia, 416: 97-106.

1156

1157 Trewavas, E. 1983. Tilapiine fishes of the genera Sarotherodon, Oreochromis and Danakila.

1158 British Museum (Natural History), 654 p.

1159

1160 Twongo, T. 1995. Impact of fish species introductions on the tilapias of Lake Victoria and

1161 Kyoga, pp. 45-57. In: T.J. Pitcher and P.J.B. Hart (Eds.), The impact of species changes in

1162 African Lakes. Fish and Fisheries Series, 18 Chapman and Hall, London.

1163

1164 Ulanowicz, R.E. 1995. The part-whole relation in ecosystems, pp.549-560. In: B.C.

1165 Patten and S.E. Jørgensen (Eds.), Complex ecology. Prentice-Hall, Englewood Cliffs, New

1166 Jersey.

1167

1168 Ulanowicz, R.E. and Puccia, C.J. 1990. The mixed trophic impact routine. Coenose, 5: 7-16

1169

1170 Ulyel, A.P. 1991. Écologie alimentaire des Haplochromis spp. (Telepstei: Cichlidae) du Lac 
1171 Kivu en Afrique Centrale. Thèse de Doctorat, Katholieke Universiteit Leuven, Département

1172 de Biologie, Écologie et de l’Aquaculture, 271 p.

1173

1174 Ulyel, A.P., Ollevier, F., Ceusters, R. and Thys van den Audenaerde, D.T. 1991. Food and

1175 feeding habits of Haplochromis (Teleostei: Cichlidae) from Lake Kivu (Central Africa) II. Daily

1176 feeding periodicity and dietary changes of some Haplochromis species under natural conditions.

1177 Belgian Journal of Zoology, 121 (2): 93-112.

1178

1179 Van den Bossche, J.P. and Bernacsek, G.M. 1990. Source book for the inland fishery resources

1180 of Africa: Volume 1, CIFA Technical Paper No.18.1, FAO, Rome, 240 pp.

1181

1182 Van der Zanden, M.J., Casselman, J.M. and Rasmussen, J.B. 1999. Stable isotope evidence for

1183 the food web consequences of species invasions in lakes. Nature, 401: 464-467.

1184

1185 Verheyen, E., Salzburger, W., Snoeks, J. and Meyer, A. 2003. Origin of the superflock of cichlid

1186 fishes from Lake Victoria, East Africa. Science, 300: 325-328.

1187

1188 Villanueva, M.C., Lalèyè, P., Albaret, J.-J., Laë, R., Tito de Morais, L. and Moreau, J. 2006.

1189 Comparative analysis of trophic structure and interactions of two tropical lagoons. Ecological

1190 Modelling, 197: 461-477.

1191

1192 Villanueva, M.C. and Moreau, J. 2001. Recent trends of evolution in Lake Victoria fisheries as

1193 assessed by Ecopath 4 (with Ecosim) software, pp. 96-110. In: I.G. Cowx (Ed.), Lake and

1194 Reservoirs Fisheries Management. The University of Hull Publication, United Kingdom. 
1196 Vitousek, P.M., D'Antonio, C.M., Loope, L.L., Rejmánek, M. and Westbrooks, R. 1997.

1197 Introduced species: A significant component of human-caused global change. New Zealand 1198 Journal of Ecology, 21(1): 1-16.

1199

1200 Volterra, V. 1931. Variations and fluctuations of the number of individuals in animal species 1201 living together, 409-448 pp. In: R.N. Chapman (Ed.), Animal Ecology. McGraw-Hill, New York 1202 and London.

1203

1204 Wanink, J.H. and Witte, F. 2000. The use of perturbation as a natural experiment: effects of 1205 predator introduction on the community structure of zooplanktivorous fish in Lake Victoria. 1206 Advances in Ecological Research, 31: 553-570.

1207

1208 Wanink, J.H., Katunzi, E.F.B., Goudswaard, K.P.C., Witte, F. and van Densen, W.L.T. 2002.

1209 The shift to smaller zooplankton in Lake Victoria cannot be attributed to the 'sardine'

1210 Rastrineobola argenta (Cyprinidae). Aquatic Living Resources, 15: 37-43.

1211

1212 Welcomme, R.L. 1988. International transfers of inland fish species. FAO Fisheries Technical 1213 Papers 294, 318 p.

1214

1215 Wilcove, D.S., Rothstein, D., Dubow, J., Phillips, A. and Losos, E. 1998. Quantifying threats to 1216 imperilled species in the United States. Bioscience, 48: 607-615. 
1218 Winfield, I.J. and Durie, N.C. 2004. Fish introductions and their management in the English 1219 Lake District. Fisheries Management and Ecology, 11: 195-201.

1220

1221 Wootton, J.T., Power, M.E., Paine, R.T. and Pfister, C.A. 1996. Effects of productivity, 1222 consumers, competitors, and El Niño events on food chain patterns in a rocky intertidal 1223 community. Proceedings of the National Academy of Sciences, 93: 13855-13858.

1224

1225 Yang, Y.F., Huang, X.F., Liu, J.K. and Jiao, N.Z. 2005. Effects of fish stocking on the 1226 zooplankton community structure in a shallow lake in China. Fisheries Management and 1227 Ecology, 12: 81-89.

1228

1229 Yodzis, P. and Winemiller, K.O. 1999. In search of operational trophospecies in a tropical 1230 aquatic food web. Ö̈kos, 87: 327-340. 


\section{List of Figures:}

Figure 1. Lake Kivu (East Africa) on the border between Republic Democratic of Congo (formerly known as Zaire) and Rwanda. The sector considered in the study is the southern basin of the lake (inside dashed frame).

Figure 2. Relative biomass and major flows connecting of functional groups considered in the Lake Kivu model. Less important flows are omitted for clarity's sake. The horizontal axis of symmetry of each box is aligned with the trophic level (TL) of the box in question. The numbered value of a TL is fractional because it depends on the diet composition of this group and on the TLs of its preys (Christensen and Pauly, 1993).

Figure 3. Prey versus predator niche overlap plot. Groups in the lower left of the figure have quite no overlap and are quite independent for both preys and predators. Groups on the upper right corner have a high overlap for both predators and preys

Figure 4. Combined trophic impacts for functional groups considered. Clear box: cumulative effects (absolute values) of an increase by $10 \%$ in biomass of all other groups to a specific group. Shaded box: sum of the absolute values of impacts of this group on other groups. Positive impacts are shown above the base line, negative impacts are shown below.

Figure 5. Cumulative impacts of fishing gear on functional groups if effort is increased by $10 \%$. Positive impacts are shown above the base line, negative impacts are shown below. 


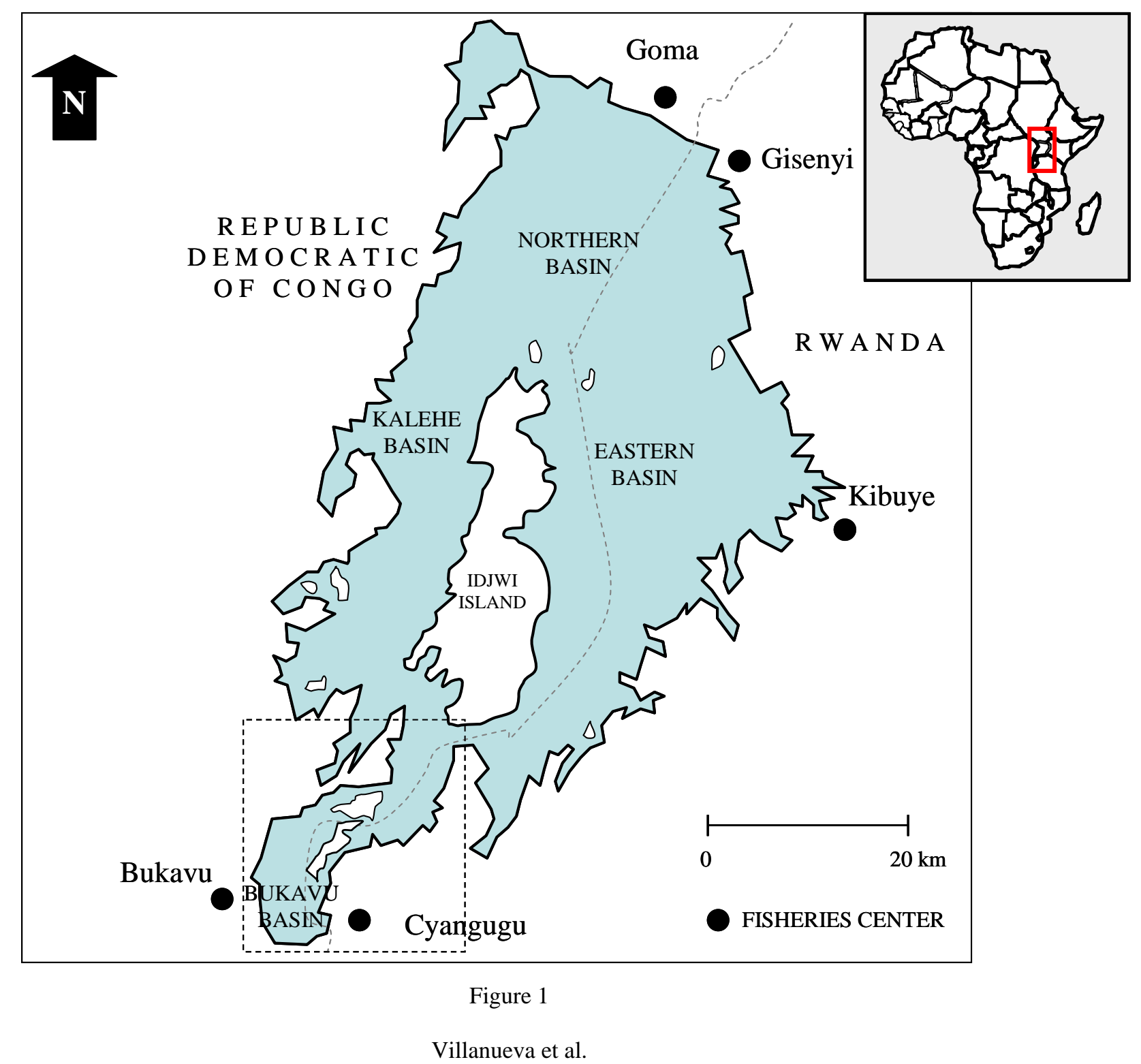




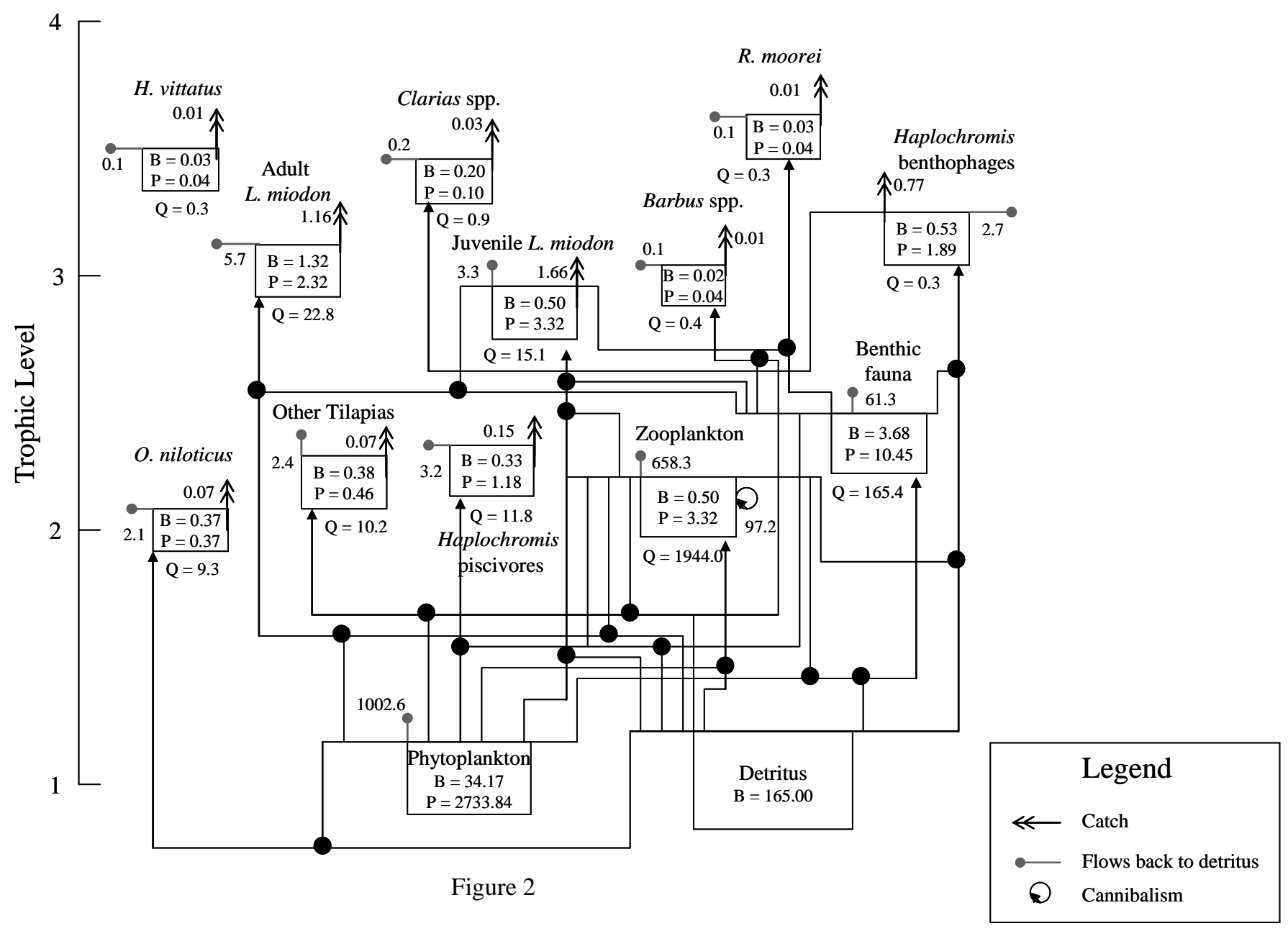

Villanueva et al. 


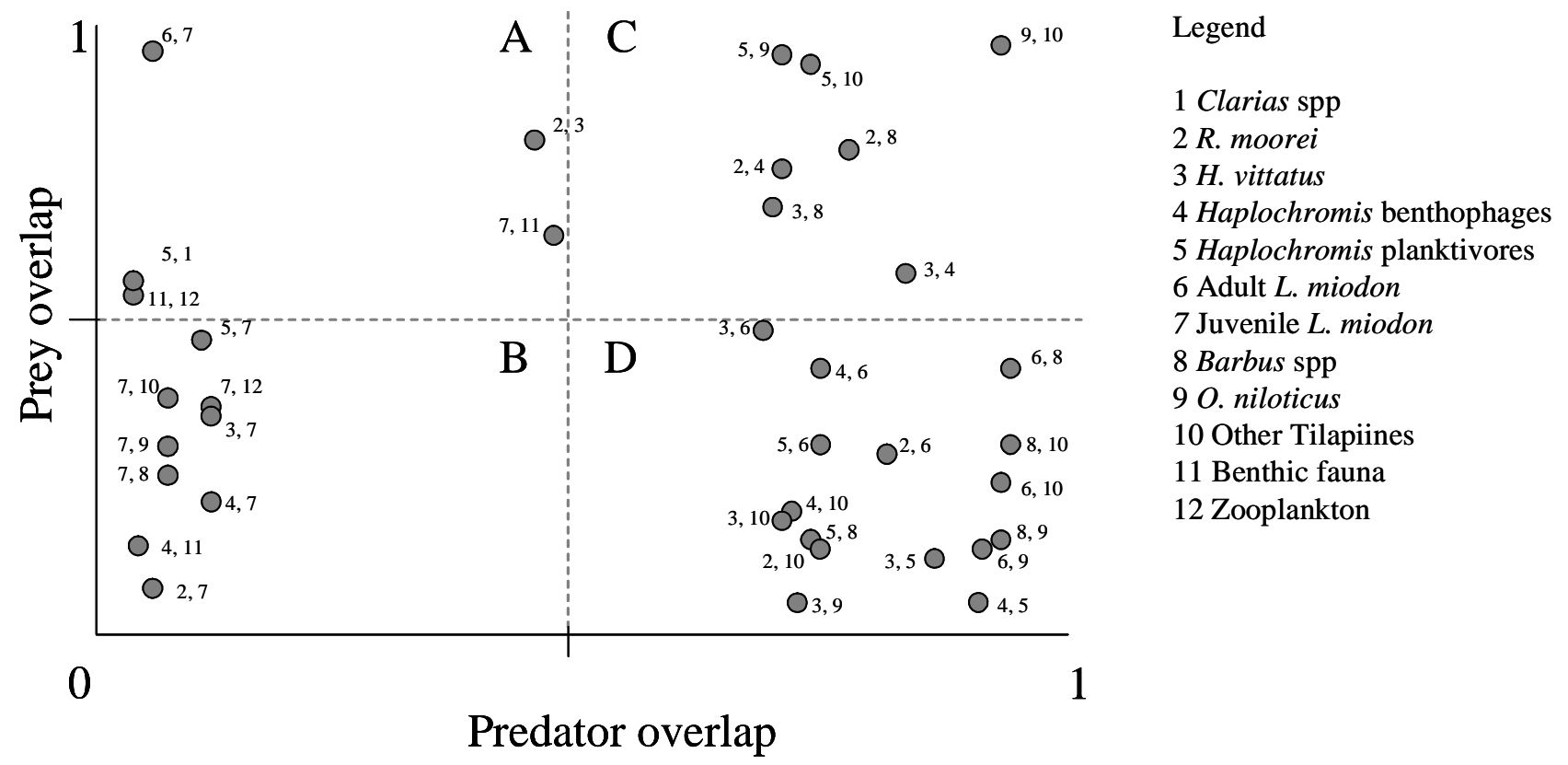

Figure 3

Villanueva et al. 


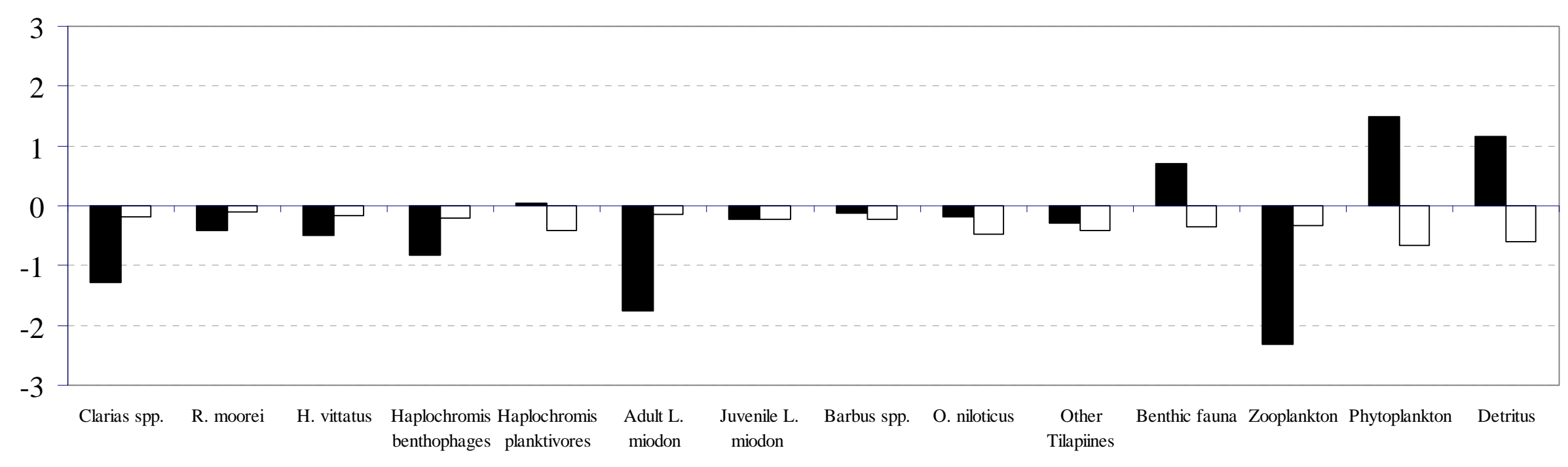

- Impacting group $\square$ Impacted group

Figure 4

Villanueva et al. 


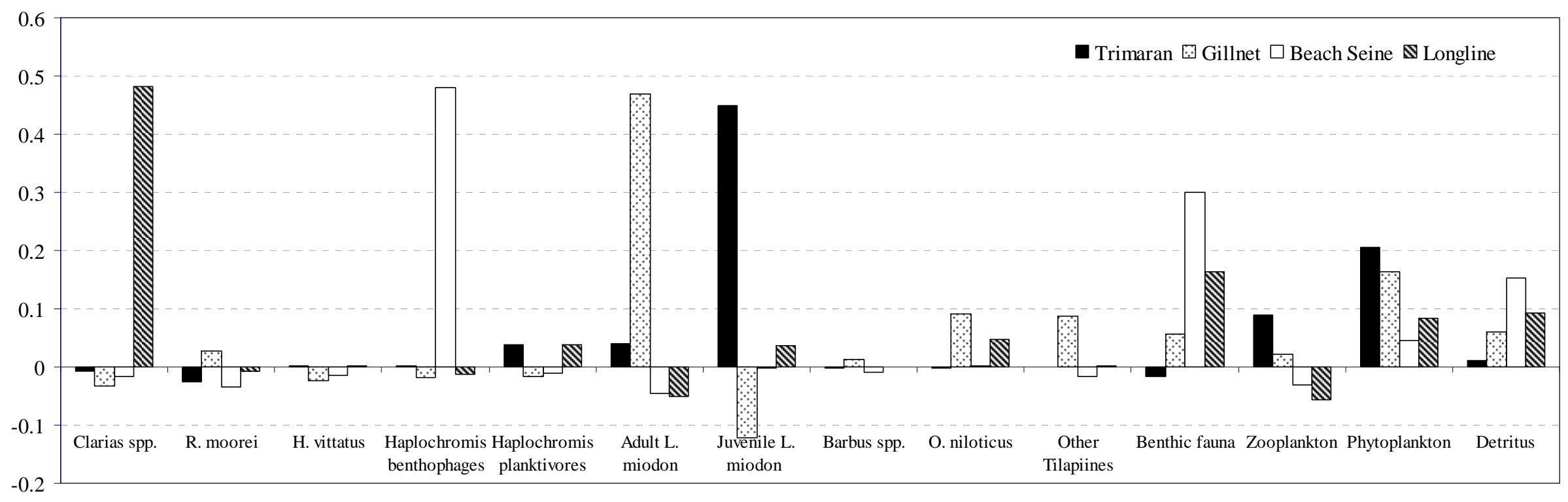

Figure 5

Villanueva et al. 
Table 1. Growth parameters for fish populations as incorporated in the model.

\begin{tabular}{lcccc}
\hline \multicolumn{1}{c}{ Species } & $\begin{array}{c}\mathbf{L}_{\infty} \\
\mathbf{( T L ~} \mathbf{~ c m})\end{array}$ & $\begin{array}{c}\mathbf{K} \\
\left(\mathbf{y r}^{-1} \mathbf{)}\right.\end{array}$ & $\begin{array}{c}\mathbf{Z} \\
\left(\mathbf{y r}^{-1}\right)\end{array}$ & $\begin{array}{c}\mathbf{M} \\
\left(\mathbf{y r} \mathbf{r}^{-1}\right)\end{array}$ \\
\hline Clarias gariepinus & $102.8^{a}$ & $0.165^{a}$ & $0.500^{a}$ & $0.363^{c}$ \\
Raiamas moorii & $23.0^{b}$ & $0.680^{b}$ & $1.640^{b}$ & $1.389^{c}$ \\
Haplochromis vittatus & $32.5^{b}$ & $0.550^{b}$ & $1.450^{b}$ & $1.100^{c}$ \\
Haplochromis graueri & $17.2^{b}$ & $1.085^{b}$ & $3.550^{b}$ & $2.049^{c}$ \\
Haplochromis nigroides & $10.7^{b}$ & $1.682^{b}$ & $3.580^{b}$ & $3.115^{c}$ \\
Adult Limnothrissa miodon & $18.0^{b}$ & $1.100^{b}$ & $1.750^{b}$ & $2.147^{c}$ \\
Juvenile Limnothrissa miodon & $15.0^{b}$ & $1.100^{b}$ & $6.690^{b}$ & $2.040^{c}$ \\
Barbus kerstenii & $11.7^{a}$ & $1.330^{a}$ & $2.786^{b}$ & $2.601^{c}$ \\
Oreochromis niloticus eduardianus & $38.7^{a}$ & $0.550^{a}$ & $1.008^{a}$ & $0.806^{c}$ \\
Oreochromis macrochir & $28.3^{a}$ & $0.653^{a}$ & $1.200^{a}$ & $1.007^{c}$ \\
\hline
\end{tabular}

${ }^{a}$ Estimated based on models of de Merona (1984) and Fröese and Binohlan (2000) based on observed maximum total length

${ }^{b}$ Computed using the FiSAT software (Gayanilo et al., 2002);

${ }^{c}$ Calculated using the predictive formula of Pauly (1980).

Table 2. Input values and calculated parameters (in bold) for the Ecopath model of the Congolese sector of Lake Kivu. TL is the trophic level, HA is the habitat area (\%), $\mathrm{B}_{\mathrm{HA}}$ is the biomass calculated for the habitat area $\left(\mathrm{t} . \mathrm{km}^{-2}\right), B$ is the total biomass $\left(\mathrm{t} . \mathrm{km}^{-2}\right), P / B$ is the production rate $\left(\mathrm{yr}^{-1}\right), Q / B$ the annual foof consumption per unit biomass $\left(\mathrm{yr}^{-1}\right), Y$ the total catch $\left(\mathrm{t} . \mathrm{km}^{-2} \mathrm{yr}^{-1}\right)$. and $E E$ is the ecotrophic efficiency .

\begin{tabular}{lcccccccc}
\hline Group name & TL & $\mathbf{H A}$ & $\boldsymbol{B}_{\text {HA }}$ & $\boldsymbol{B}$ & $\boldsymbol{P} / \boldsymbol{B}$ & $\boldsymbol{Q} / \boldsymbol{B}$ & $\boldsymbol{Y}^{\mathrm{d}}$ & $\boldsymbol{E} \boldsymbol{E}$ \\
\hline Clarias spp & $\mathbf{3 . 3 6}$ & 1.0 & $\mathbf{0 . 2 0 4}$ & $0.204^{\mathrm{a}}$ & $0.50^{\mathrm{c}}$ & $4.30^{\mathrm{e}}$ & 0.028 & $\mathbf{0 . 2 7 5}$ \\
Raiamas moorei & $\mathbf{3 . 5 6}$ & 1.0 & $\mathbf{0 . 0 2 5}$ & $\mathbf{0 . 0 2 5}$ & $1.64^{\mathrm{c}}$ & $21.03^{\mathrm{f}}$ & 0.010 & $0.500^{\mathrm{d}}$ \\
Haplochromis vittatus & $\mathbf{3 . 4 2}$ & 1.0 & $\mathbf{0 . 0 2 9}$ & $0.029^{\mathrm{a}}$ & $1.45^{\mathrm{c}}$ & $10.04^{\mathrm{e}}$ & 0.010 & $\mathbf{0 . 7 9 7}$ \\
Haplochromis benthivores & $\mathbf{3 . 1 5}$ & 0.1 & $\mathbf{5 . 3 2 0}$ & $0.532^{\mathrm{a}}$ & $3.55^{\mathrm{c}}$ & $17.56^{\mathrm{e}}$ & 0.773 & $\mathbf{0 . 5 4 4}$ \\
Haplochromis planktivores & $\mathbf{2 . 2 0}$ & 1.0 & $\mathbf{0 . 3 2 9}$ & $0.329^{\mathrm{a}}$ & $3.58^{\mathrm{c}}$ & $35.80^{\mathrm{e}}$ & 0.153 & $\mathbf{0 . 2 7 9}$ \\
L. miodon adults & $\mathbf{3 . 0 4}$ & 1.0 & $\mathbf{1 . 3 2 4}$ & $1.324^{\mathrm{b}}$ & $1.75^{\mathrm{c}}$ & $17.20^{\mathrm{f}}$ & 1.159 & $\mathbf{0 . 5 1 1}$ \\
L.miodon juveniles & $\mathbf{2 . 8 0}$ & 1.0 & $\mathbf{0 . 4 9 6}$ & $0.496^{\mathrm{b}}$ & $6.69^{\mathrm{c}}$ & $30.36^{\mathrm{f}}$ & 1.659 & $\mathbf{0 . 9 1 7}$ \\
Barbus spp & $\mathbf{2 . 9 8}$ & 0.1 & $\mathbf{0 . 1 5 6}$ & $\mathbf{0 . 0 1 6}^{\mathrm{d}}$ & $2.79^{\mathrm{c}}$ & $27.86^{\mathrm{e}}$ & 0.010 & $0.500^{\mathrm{d}}$ \\
O. niloticus eduardianus & $\mathbf{2 . 0 0}$ & 0.1 & $\mathbf{3 . 6 7 0}$ & $0.367^{\mathrm{a}}$ & $1.01^{\mathrm{c}}$ & $25.39^{\mathrm{e}}$ & 0.075 & $\mathbf{0 . 4 7 9}$ \\
Other Tilapiine fish & $\mathbf{2 . 1 8}$ & 0.1 & $\mathbf{3 . 8 3 0}$ & $0.383^{\mathrm{a}}$ & $1.20^{\mathrm{c}}$ & $26.74^{\mathrm{e}}$ & 0.074 & $\mathbf{0 . 2 3 3}$ \\
Benthic fauna & $\mathbf{2 . 3 2}$ & 0.1 & $\mathbf{3 6 . 7 5 7}$ & $\mathbf{3 . 6 7 6}$ & $4.50^{\mathrm{d}}$ & $45.00^{\mathrm{d}}$ & & $0.900^{\mathrm{d}}$ \\
Zooplankton & $\mathbf{2 . 0 5}$ & 1.0 & $\mathbf{1 0 . 8 0 0}$ & 10.800 & $26.00^{\mathrm{d}}$ & $180.00^{\mathrm{d}}$ & & $\mathbf{0 . 6 2 6}$ \\
Phytoplankton & & 1.0 & $\mathbf{3 4 . 1 7 3}$ & 34.173 & $80.00^{\mathrm{d}}$ & - & & $\mathbf{0 . 6 3 3}$ \\
Detritus & & 1.0 & $\mathbf{1 6 5 . 0 0}$ & $165.00^{\mathrm{d}}$ & - & - & & $\mathbf{0 . 1 5 1}$ \\
\hline
\end{tabular}

${ }^{a}$ Biomass $(B)$ was estimated when possible directly from the ratio between catch $(Y)$ and annual fishing mortality as computed in Ecopath $(B=Y / F)$;

${ }^{\mathrm{b}}$ Based on echo sound data by Lambœuf (1991). Biomass of adults are higher $\left(1.324 \mathrm{tkm}^{-2}\right)$ than those of their juveniles $\left(0.496 \mathrm{tkm}^{-2}\right)$ due to the demographical structure of the population.

${ }^{c} P / B$ of functional group is assumed equal to the total mortality estimated (cf. Table 1$)$;

${ }^{\mathrm{d}}$ Sources indicated in text;

e Estimated using the predictive model of Palomares and Pauly (1998);

${ }^{\mathrm{f}}$ Estimated using the MAXIMS software (Jarre et al., 1991). 
Table 3. Diet composition (\%) of the groups considered in the Ecopath model of the Lake Kivu Congolese sector.

\begin{tabular}{|c|c|c|c|c|c|c|c|c|c|c|c|c|c|}
\hline & Group name & $\mathbf{1}^{\mathrm{a}}$ & $2^{b}$ & $3^{c}$ & $4^{d}$ & $5^{e}$ & $6^{b}$ & $7^{f}$ & $8^{g}$ & $9^{h}$ & $10^{i}$ & $11^{\mathrm{j}}$ & $12^{\mathrm{k}}$ \\
\hline 1 & Clarias spp & & & & & & & & & & & & \\
\hline 2 & Raiamas moorei & 0.005 & & 0.020 & & & & & & & & & \\
\hline 3 & Haplochromis vittatus & 0.015 & 0.02 & & & & & & & & & & \\
\hline 4 & Haplochromis benthivores & 0.120 & 0.15 & 0.200 & & & & & 0.03 & & & & \\
\hline 5 & Haplochromis planktivores & 0.090 & 0.10 & 0.080 & & & & & 0.05 & & & & \\
\hline 6 & L. miodon adult & 0.020 & & 0.025 & & & & & & & & & \\
\hline 7 & L.miodon juvenile & 0.100 & 0.25 & 0.100 & & & 0.05 & & & & & & \\
\hline 8 & Barbus spp & 0.010 & & 0.010 & & & & & & & & & \\
\hline 9 & O. niloticus eduardianus & 0.100 & & 0.050 & & & & & & & & & \\
\hline 10 & Other Tilapiine fish & 0.030 & & 0.025 & & & & & & & & & \\
\hline 11 & Benthic fauna & 0.400 & 0.46 & 0.270 & 0.78 & 0.03 & 0.20 & 0.05 & 0.57 & & 0.10 & & \\
\hline 12 & Zooplankton & 0.040 & 0.01 & 0.150 & 0.12 & 0.15 & 0.65 & 0.70 & 0.10 & & 0.05 & 0.30 & 0.05 \\
\hline 13 & Phytoplankton & 0.020 & 0.01 & 0.020 & 0.01 & 0.8 & 0.09 & 0.23 & 0.05 & 0.80 & 0.65 & 0.30 & 0.85 \\
\hline 14 & Detritus & 0.050 & & 0.050 & 0.09 & 0.02 & 0.01 & 0.02 & 0.20 & 0.20 & 0.20 & 0.40 & 0.10 \\
\hline
\end{tabular}

a. Diet composition based on indications of Mavuti et al. (1996) and from Fröese and Pauly (2006);

b. From Kaningini et al. (1999);

c. Ulyel (1991) and Kaningini et al. (1999);

d. Considered diet composition of Haplochromis graueri (Ulyel, 1991);

e. Considered diet composition of Haplochromis kamiranzovu (Ulyel, 1991);

f. Kaningini et al. (1999) and Roest (1999);

g. M. Isumbisho (UERAH, unpublished data);

h. From Trawavas (1983) and B Kaningini (UERAH, pers. omm..);

i. Considered diet composition of $O$. macrochir from Fröese and Pauly (2006);

j. Based on indications of Christensen and Pauly (1993);

Table 52. From Christensen and Pauly (1993) and Sarvala et al. (2003).

Table 4. Ecological characteristics of the groups considered in the model. $P / Q$ is the production/consumption ratio, FtD is the flow to detritus $\left(\mathrm{t} \mathrm{km}^{-2} \mathrm{yr}^{-1}\right), N E$ is the net efficiency and $O I$ is the omnivory index.

\begin{tabular}{lcccc}
\hline Group name & $\mathbf{P} / \mathbf{Q}$ & $\boldsymbol{F t D}$ & $\boldsymbol{N E}$ & $\boldsymbol{O I}$ \\
\hline Clarias spp & 0.116 & 0.249 & 0.145 & 0.282 \\
Raiamas moorei & 0.078 & 0.124 & 0.097 & 0.150 \\
Haplochromis vittatus & 0.144 & 0.067 & 0.181 & 0.339 \\
Haplochromis benthivores & 0.202 & 2.730 & 0.253 & 0.155 \\
Haplochromis planktivores & 0.100 & 3.205 & 0.125 & 0.179 \\
L. miodon adult & 0.102 & 5.688 & 0.127 & 0.153 \\
L.miodon juvenile & 0.220 & 3.286 & 0.275 & 0.218 \\
Barbus spp & 0.100 & 0.108 & 0.125 & 0.349 \\
O. niloticus eduardianus & 0.040 & 2.057 & 0.050 & 0.000 \\
Autres Tilapiine fish & 0.045 & 2.401 & 0.056 & 0.195 \\
Benthic fauna & 0.100 & 51.277 & 0.143 & 0.233 \\
Zooplankton & 0.144 & 688.307 & 0.206 & 0.053 \\
Phytoplankton & - & 1002.627 & - & 0.000 \\
Detritus & - & 0.000 & - & 0.298 \\
\hline
\end{tabular}


Table 5. The trophic structure of the Lake Kivu ecosystem (Congolese sector) as estimated by the Ecopath software.

\begin{tabular}{cccccc}
\hline $\begin{array}{c}\text { Trophic level } \\
\text { (TL) }\end{array}$ & $\begin{array}{c}\text { Catch } \\
\left(\mathrm{t} \mathrm{km}^{-2} \mathrm{yr}^{-1}\right)\end{array}$ & $\begin{array}{c}\text { (\%) per } \\
\text { TL }\end{array}$ & $\begin{array}{c}\text { Biomass } \\
\left(\mathrm{t} \mathrm{km}^{-2}\right)\end{array}$ & \% per TL & $\begin{array}{c}\text { Transfer efficiency } \\
(\%)\end{array}$ \\
\hline V & 0.0031 & 0.08 & 0.012 & 0.32 & 4.60 \\
IV & 0.3405 & 8.62 & 0.365 & 9.86 & 7.60 \\
III & 2.7310 & 69.12 & 2.034 & 54.93 & 9.40 \\
II & 0.8767 & 22.19 & 1.292 & 34.89 & 4.50 \\
\hline
\end{tabular}

Proportion of total flow originating from detritus: $\quad 0.31$

Transfer efficiencies: 1) From primary producers: $\quad 6.80 \%$
2) From detritus:
$7.10 \%$

Total:

$6.90 \%$

Table 6. Summary statistics of Lake Kivu.

\begin{tabular}{|c|c|c|}
\hline Parameter & Value & Units \\
\hline Sum of all consumption & 2190.04 & $\mathrm{t} \cdot \mathrm{km}^{-2} \cdot \mathrm{yr}^{-1}$ \\
\hline Sum of all exports & 1499.85 & $\mathrm{t} . \mathrm{km}^{-2} \cdot \mathrm{yr}^{-1}$ \\
\hline Sum of all respiratory flows & 1233.99 & t. $\mathrm{km}^{-2} \cdot \mathrm{yr}^{-1}$ \\
\hline Sum of all flows into detritus & 1762.12 & t. $\mathrm{km}^{-2} \cdot \mathrm{yr}^{-1}$ \\
\hline Total system throughput & 6686.00 & t. $\mathrm{km}^{-2} \cdot \mathrm{yr}^{-1}$ \\
\hline Sum of all production & 3040.00 & t. $\mathrm{km}^{-2} \cdot \mathrm{yr}^{-1}$ \\
\hline Mean trophic level of the catch & 2.90 & \\
\hline Gross efficiency (catch/net p.p.) & 0.001445 & \\
\hline Input total net primary production & 2733.84 & t. $\mathrm{km}^{-2} \cdot \mathrm{yr}^{-1}$ \\
\hline Calculated total net primary production & 2733.84 & t. $\mathrm{km}^{-2} \cdot \mathrm{yr}^{-1}$ \\
\hline Total primary production/total respiration & 2.21 & \\
\hline Net system production & 1499.85 & t. $\mathrm{km}^{-2} \cdot \mathrm{yr}^{-1}$ \\
\hline Total primary production/total biomass & 52.22 & \\
\hline Total biomass/total throughput & 0.008 & \\
\hline Total biomass (excluding detritus) & 52.35 & t.km² \\
\hline Total catch & 3.95 & t. $\mathrm{km}^{-2} \cdot \mathrm{yr}^{-1}$ \\
\hline Connectance Index (CI) & 0.396 & \\
\hline System Omnivory Index (SOI) & 0.148 & \\
\hline
\end{tabular}

